Marquette University

e-Publications@Marquette

Biological Sciences Faculty Research and

Publications

Biological Sciences, Department of

5-5-2015

Inactivation of Mandelate Racemase by 3-Hydroxypyruvate Reveals a Potential Mechanistic Link between Enzyme Superfamilies

Mitesh Nagar

Dalhousie University

Brittney N. Wyatt

Marquette University

Martin St. Maurice

Marquette University, martin.stmaurice@marquette.edu

Stephen L. Bearne

Dalhousie University

Accepted version. Biochemistry, Vol. 54, No. 17 (May 5, 2015): 2747-2757. DOI. (C) 2015 American Chemical Society. Used with permission. 


\title{
Inactivation of Mandelate Racemase by 3-Hydroxypyruvate Reveals a Potential Mechanistic Link between Enzyme Superfamilies
}

\author{
Mitesh Nagar \\ Department of Biochemistry and Molecular Biology, \\ Dalhousie University, \\ Halifax, Canada \\ Brittney N. Wyatt \\ Department of Biological Sciences, Marquette University, \\ Milwaukee, WI \\ Martin St. Maurice \\ Department of Biological Sciences, Marquette University, \\ Milwaukee, WI \\ Stephen L. Bearne \\ Department of Biochemistry and Molecular Biology, \\ Department of Chemistry, \\ Dalhousie University, \\ Halifax, Canada
}




\section{Abstract}

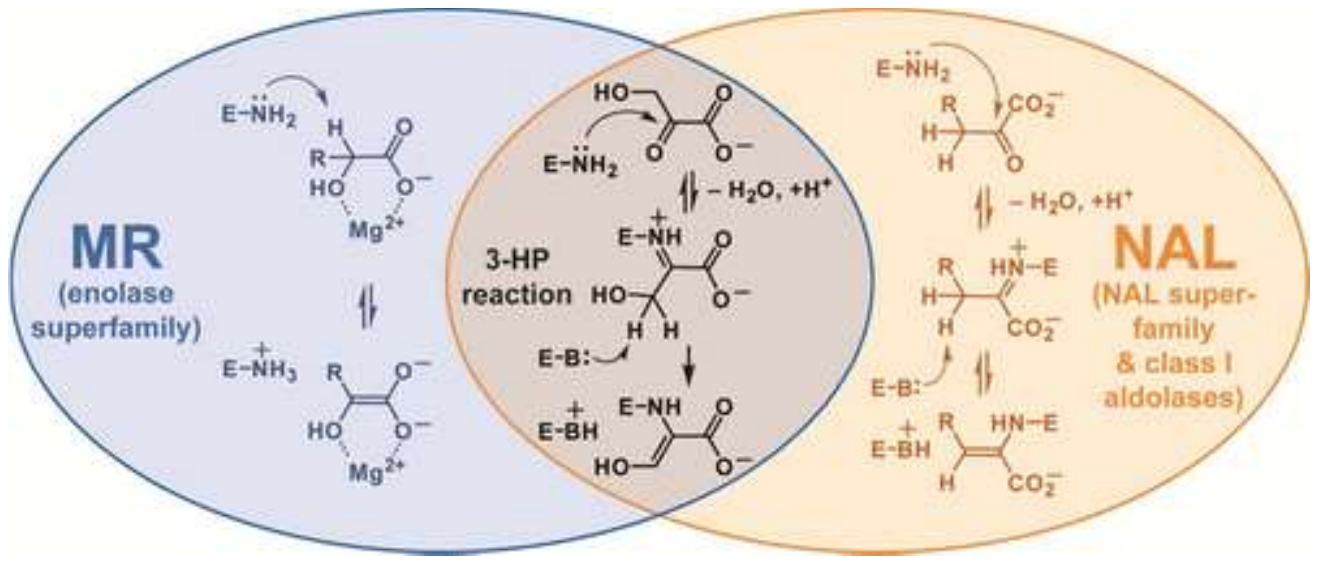

Mandelate racemase (MR), a member of the enolase superfamily, catalyzes the $\mathrm{Mg}^{2+}$-dependent interconversion of the enantiomers of mandelate. Several a-keto acids are modest competitive inhibitors of MR [e.g., mesoxalate $\left(K_{\mathrm{i}}=\right.$ $1.8 \pm 0.3 \mathrm{mM})$ and 3 -fluoropyruvate $\left.\left(K_{\mathrm{i}}=1.3 \pm 0.1 \mathrm{mM}\right)\right]$, but, surprisingly, 3-hydroxypyruvate (3-HP) is an irreversible, time-dependent inhibitor $\left(k_{\text {inact }} / K_{\mathrm{I}}=83 \pm 8 \mathrm{M}^{-1} \mathrm{~s}^{-1}\right)$. Protection from inactivation by the competitive inhibitor benzohydroxamate, trypsinolysis and electrospray ionization tandem mass spectrometry analyses, and X-ray crystallographic studies reveal that 3HP undergoes Schiff-base formation with Lys 166 at the active site, followed by formation of an aldehyde/enol(ate) adduct. Such a reaction is unprecedented in the enolase superfamily and may be a relic of an activity possessed by a promiscuous progenitor enzyme. The ability of MR to form and deprotonate a Schiff-base intermediate furnishes a previously unrecognized mechanistic link to other $a / \beta$-barrel enzymes utilizing Schiff-base chemistry and is in accord with the sequence- and structure-based hypothesis that members of the metal-dependent enolase superfamily and the Schiff-baseforming $N$-acetylneuraminate lyase superfamily and aldolases share a common ancestor.

One of the first enzyme superfamilies recognized was the enolase superfamily, ${ }^{1}$ whose members share a common partial reaction (i.e., the metal-assisted, Brønsted-base-catalyzed abstraction of the a-proton from a carboxylate substrate to form an enolate $)^{2-5}$ and a common protein fold [i.e., a modified $(a / \beta)_{8}$-barrel (TIM barrel) bearing the catalytic residues at the $\mathrm{C}$-terminal ends of the $\beta$-strands and an $\mathrm{N}$-terminal domain that caps the active site conferring substrate specificity and excluding solvent]. ${ }^{6-8}$ Studies of members of the enolase superfamily have afforded important insights into enzyme evolution and developing strategies for assigning the correct functions to proteins identified in genome projects. ${ }^{3,9-12}$ The well-characterized 
archetype of this superfamily, mandelate racemase (MR, EC 5.1.2.2) from Pseudomonas putida, catalyzes the $\mathrm{Mg}^{2+}$-dependent, 1,1-proton transfer reaction that interconverts the enantiomers of mandelate and has served as a useful paradigm for understanding how enzymes catalyze the rapid a-deprotonation of a carbon acid substrate with a relatively high $\mathrm{p} K_{\mathrm{a}}$ value. ${ }^{13}$

MR utilizes a two-base mechanism with Lys 166 and His 297 abstracting the a-proton from $(S)$ - and $(R)$-mandelate, respectively (Scheme 1). A variety of $\beta / \gamma$-unsaturated compounds, ${ }^{14-21}$ as well as trifluorolactate, ${ }^{22}$ serve as substrates for the enzyme. Recently, we showed that the substrate-product analogue 3,3,3-trifluoro-2hydroxy-2-(trifluoromethyl)propionate [TFHTP (Chart 1)] is a potent competitive inhibitor of MR $\left(K_{\mathrm{i}}=27 \mu \mathrm{M}\right)$ and that its unexpectedly high binding affinity arises from both intimate interactions between the trifluoromethyl groups and the hydrophobic pocket at the active site, and formation of salt bridges between the carboxylate of TFHTP and the active site Brønsted acid-base catalysts Lys 166 and His 297.23 Recognizing that these active site bases can be exploited as binding determinants for inhibitors, we showed that tartronate is also a competitive inhibitor of $\mathrm{MR}\left(K_{\mathrm{i}}=1.8 \mathrm{mM}\right)$, binding with its glycolate moiety chelating the $\mathrm{Mg}^{2+}$ ion and with the remaining carboxylate group interacting with and bridging the active site Brønsted acid-base catalysts. ${ }^{23}$ Our interest in understanding the role of the active site Brønsted acid-base catalysts as binding determinants led us to interrogate the active site using three-carbon a-keto acids as tartronate analogues. Most unexpectedly, we discovered that 3hydroxypyruvate (3-HP) is an irreversible inhibitor of $M R$, reacting at the active site to form a Schiff-base intermediate that is subsequently deprotonated to form an aldehyde/enol(ate) adduct. Such a reaction has not been reported previously for any member of the enolase superfamily and suggests a mechanistic link to other enzyme superfamilies utilizing Schiff-base chemistry.

Biochemistry, Vol 54, No. 17 (May 5, 2015): pg. 2747-2757. DOI. This article is (C) American Chemical Society and permission has been granted for this version to appear in e-Publications@Marquette. American Chemical Society does not grant permission for this article to be further copied/distributed or hosted elsewhere without the express permission from American Chemical Society. 
<smiles>COC(=O)C(=O)C(=O)[O-]</smiles>

mesoxalate<smiles>CC(=O)C(=O)[O-]</smiles>

pyruvate<smiles>COC(=O)C(O)C(=O)[O-]</smiles>

tartronate<smiles>O=C([O-])C(=O)O</smiles>

3-hydroxypyruvate (3-HP)<smiles>O=C([O-])C(=O)F</smiles>

3-fluoropyruvate (3-FP)<smiles>O=C([O-])C(=O)c1ccccc1</smiles>

benzoylformate<smiles>O=C([O-])C(O)(C(F)(F)F)C(F)(F)F</smiles>

TFHTP<smiles>[O-]/N=C(\O)c1ccccc1</smiles>

benzohydroxamate $(\mathrm{BzH})$

Chart 1. Structures of Ligands<smiles>O=C([OH2+])[C@H](O)c1ccccc1</smiles>

(R)-mandelate

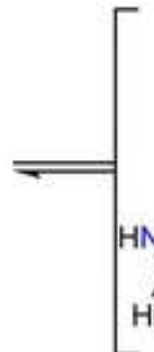

His 297 aci-carboxylate intermediate

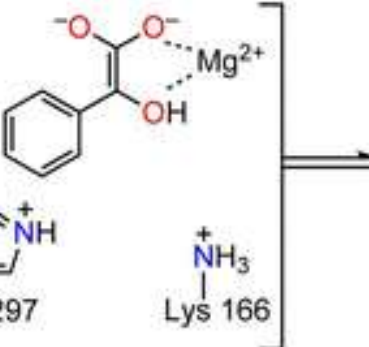

Scheme 1. Reaction Catalyzed by Mandelate Racemase

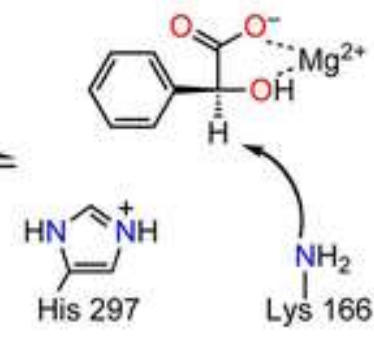

(S)-mandelate

\section{Materials and Methods}

\section{General}

(R)-Mandelic acid, lithium 3-hydroxypyruvate (3-HP), sodium mesoxalate monohydrate, benzoylformic acid, sodium pyruvate, benzohydroxamic acid, sodium 3-fluoropyruvate monohydrate (3-FP), and all other reagents, unless mentioned otherwise, were purchased from Sigma-Aldrich Canada Ltd. Circular dichroism (CD)-based assays were conducted using a JASCO J-810 spectropolarimeter with a thermostated, water-jacketed cell holder. High-resolution electrospray ionization (ESI) mass spectrometry (MS) was conducted using a Brüker microTOF Focus orthogonal ESI-time-of-flight mass spectrometer operating in positive ion mode. 
NOT THE PUBLISHED VERSION; this is the author's final, peer-reviewed manuscript. The published version may be accessed by following the link in the citation at the bottom of the page.

\section{Concentration Correction for 3-HP}

Elemental analysis (Canadian Microanalytical Services Inc.) was conducted on the lithium salt of 3-HP purchased from Sigma-Aldrich to obtain an accurate estimate of the extent of hydration. On the basis of the presence of $26.13 \%$ carbon and $3.63 \%$ hydrogen in the sample, the calculated molecular weight of $3-\mathrm{HP}$ was 137.89 , which corresponds to $\mathrm{C}_{3} \mathrm{H}_{3} \mathrm{O}_{4} \mathrm{Li} \cdot \sim 1.5 \mathrm{H}_{2} \mathrm{O}$.

\section{Site-Directed Mutagenesis}

The pET52b(+)-wtMR plasmid ${ }^{24}$ was used as the template to create the $\mathrm{H} 297 \mathrm{~N}$ mandelate racemase (MR) mutant by performing polymerase chain reaction ( $P C R$ )-based site-directed mutagenesis using the QuikChange Site-directed Mutagenesis Kit (Stratgene) and following the protocols described by the manufacturer. Polymerase chain reactions were conducted using PfuTurbo DNA polymerase (Bio Basic Inc.). The forward and reverse synthetic deoxyoligonucleotide primers (Integrated DNA Technologies, Inc.) used to construct the mutant were 5'-CCAATGTCCAGCAACCTGTTCCAAGAAATCAGC-3' and 5'-GCTGATTTCTTGGAACAGGTTGCTGGACATTGG-3', respectively. The codons specifying the relevant amino acid are underlined, and the altered bases are given in boldface. Potential mutant plasmids were used to transform competent Escherichia coli DH5a cells. DH5a cells were used for plasmid maintenance and for all sequencing reactions. The mutant open reading frame was sequenced using commercial automated DNA sequencing (Robarts Research Institute) to ensure that no other alterations of the nucleotide sequence had been introduced.

\section{Enzyme Purification}

Recombinant wild-type (wtMR) and H297N MR from Pseudomonas putida were overexpressed in and purified from $E$. coli BL21(DE3) cells transformed with the pET-52b(+)-wtMR and pET$52 \mathrm{~b}(+)-\mathrm{H} 297 \mathrm{~N}-\mathrm{MR}$ plasmids, respectively. The pET-52b(+)-wtMR plasmid containing the MR variant open reading frame encodes the MR gene product (MASWSHPQFEKGALEVLFQGPGYHM ${ }_{1} \ldots$ MR) with an N-

Biochemistry, Vol 54, No. 17 (May 5, 2015): pg. 2747-2757. DOI. This article is (C) American Chemical Society and permission has been granted for this version to appear in e-Publications@Marquette. Ame rican Chemical Society does not grant permission for this article to be further copied/distributed or hosted elsewhere without the express permission from American Chemical Society. 
terminal StrepII tag (underlined; $M_{1}$ represents the first amino acid of wild-type MR). ${ }^{24}$ The wild-type and mutant enzymes were purified by affinity chromatography using Strep-Tactin Superflow resin (IBA $\mathrm{GmbH}$ ) and an ÄKTA FPLC instrument (GE Healthcare) as described previously. ${ }^{24}$ Upon elution from the column, the enzyme was dialyzed against storage buffer [100 mM HEPES buffer ( $\mathrm{pH} 7.5)$ containing 3.3 $\mathrm{mM} \mathrm{MgCl}, 200 \mathrm{mM} \mathrm{NaCl}$, and $10 \%$ (v/v) glycerol] and stored at $-20{ }^{\circ} \mathrm{C}$. The purity of the enzyme preparation $(\geq 99 \%)$ was checked using $12 \%$ sodium dodecyl sulfate-polyacrylamide gel electrophoresis (SDS-PAGE). StrepII-tagged MR has the same activity as the wildtype enzyme; ${ }^{24}$ consequently, the StrepII tag was not removed from the enzymes.

\section{Enzyme Assays}

MR activity was assayed using a CD-based assay by following the change in ellipticity of mandelate at $262 \mathrm{~nm}$ using a thermostated quartz cuvette with a $1-\mathrm{cm}$ light path (unless otherwise indicated) as described by Sharp et al. ${ }^{25}$ All assays (total volume of $2 \mathrm{~mL}$ ) were conducted at $25^{\circ} \mathrm{C}$ in $\mathrm{Na}^{+}$-HEPES buffer $(0.1 \mathrm{M}, \mathrm{pH} 7.5)$ containing $\mathrm{MgCl}_{2}(3.3 \mathrm{mM}), \mathrm{BSA}[0.005 \%(\mathrm{w} / \mathrm{v})]$, and $(R)$-mandelate as the substrate. The concentration of MR was determined from its absorbance at $280 \mathrm{~nm}$ using an extinction coefficient of $53400 \mathrm{M}^{-1} \mathrm{~cm}^{-}$ 1 , which was calculated using the ProtParam tool available on the ExPASy server (http://web.expasy.org/protparam). ${ }^{26}$ All kinetic parameters were determined in triplicate, and average values are reported. The reported errors are the standard deviations.

\section{Initial Screening of a-Keto Acids for Time-Dependent Inhibition of $M R$}

Wild-type MR (32.7 nM) was incubated with either pyruvate $(10.0 \mu \mathrm{M})$, mesoxalate $(10.0 \mu \mathrm{M})$, 3-FP $(10.0 \mu \mathrm{M})$, benzoylformate $(10.0 \mu \mathrm{M})$, or $3-\mathrm{HP}(8.0 \mu \mathrm{M})$ in the presence of BSA [0.05\% $(\mathrm{w} / \mathrm{v})]$ at $25{ }^{\circ} \mathrm{C}$ for $0,6,12,18$, and $24 \mathrm{~min}$. At each time point, $200 \mu \mathrm{L}$ of the enzyme/inhibitor mixture was added to assay buffer containing $(R)$ mandelate to determine the MR activity. The residual MR activity was measured using the CD-based assay by following the change in ellipticity of mandelate at $262 \mathrm{~nm}$ for $3 \mathrm{~min}$ in a quartz cuvette with a 
1-cm light path $(0.5-\mathrm{cm}$ light path length when the inhibition by benzoylformate was assessed). The final concentrations of MR, BSA, inhibitor, and $(R)$-mandelate in the $2.0 \mathrm{~mL}$ assay mixture were $3.3 \mathrm{nM}$, $0.005 \%(\mathrm{w} / \mathrm{v}), 1.0 \mu \mathrm{M}$ (except for that of $3-\mathrm{HP}$, which was $0.8 \mu \mathrm{M}$ ), and $10 \mathrm{mM}$, respectively. Simultaneously, a control reaction mixture containing wild-type MR (32.7 nM) was incubated in assay buffer at $25^{\circ} \mathrm{C}$ for 0 and 30 min to determine the rate of loss of MR activity under the incubation conditions in the absence of inhibitor. Similar time-dependent inhibition experiments were also conducted for pyruvate, mesoxalate, benzoylformate, and 3-FP at a greater inhibitor concentration ( $2 \mathrm{mM}$ ) for 0 and $10 \mathrm{~min}$. The final concentrations of $\mathrm{MR}$, inhibitor, and $(R)$-mandelate were equal to $3.3 \mathrm{nM}, 0.2 \mathrm{mM}$, and $10 \mathrm{mM}$, respectively, in a total reaction volume of $2.0 \mathrm{~mL}$ for the activity assays.

\section{Inhibition of MR by Mesoxalate and 3-FP}

Inhibition experiments were conducted in $\mathrm{Na}^{+}$-HEPES buffer $(0.1$ $\mathrm{M}, \mathrm{pH}$ 7.5) containing $\mathrm{MgCl}_{2}(3.3 \mathrm{mM}), \mathrm{BSA}[0.005 \%(\mathrm{w} / \mathrm{v})],(R)-$ mandelate $(0.25-10.0 \mathrm{mM}), \mathrm{MR}(3.0 \mathrm{nM})$, and either mesoxalate $(0$, $1.0,2.0$, and $4.0 \mathrm{mM})$ or $3-\mathrm{FP}(0,0.75,1.5$, and $3.0 \mathrm{mM})$ in a total reaction volume of $2.0 \mathrm{~mL}$. The apparent kinetic constants $V_{\max }$ and $K_{\mathrm{m}}$ were determined by fitting eq 1 to the initial velocity data using nonlinear regression analysis and KaleidaGraph version 4.02 from Synergy Software. Competitive inhibition constants $\left(K_{i}\right)$ were determined from plots of the apparent $K_{\mathrm{m}} / V_{\max }$ values versus inhibitor concentration in accord with eq 2.

$$
\begin{gathered}
v_{\mathrm{i}}=\frac{V_{\max }[\mathrm{S}]}{K_{\mathrm{m}}+[\mathrm{S}]}(1) \\
v_{\mathrm{i}}=\frac{V_{\max }[\mathrm{S}]}{K_{\mathrm{m}}\left(1+\frac{[1]}{K_{\mathrm{i}}}\right)+[\mathrm{S}]}
\end{gathered}
$$

\section{Inactivation of $M R$ by $3-H P$}

The kinetic parameters for the time-dependent inhibition of MR by 3-HP were determined by incubating wild-type MR (32.7 nM) with

Biochemistry, Vol 54, No. 17 (May 5, 2015): pg. 2747-2757. DOI. This article is (C) American Chemical Society and permission has been granted for this version to appear in e-Publications@Marquette. Ame rican Chemical Society does not grant permission for this article to be further copied/distributed or hosted elsewhere without the express permission from American Chemical Society. 
various concentrations of 3-HP $(0,3.99,7.98,11.97$, and $15.95 \mu \mathrm{M})$ in the presence of BSA $[0.05 \%(\mathrm{w} / \mathrm{v})]$ at $25^{\circ} \mathrm{C}$ for $0,6,12,18$, and 24 min. At each time point, an aliquot $(200 \mu \mathrm{L})$ of the reaction mixture was added to the assay solution (total volume of $2.0 \mathrm{~mL}$ ) containing $(R)$-mandelate (final concentration of $10 \mathrm{mM}$ ) to determine the remaining MR activity as described above. The observed pseudo-firstorder rate constant for the inactivation of $\mathrm{MR}$ ( $\left.k_{\mathrm{obs}}\right)$ at each inhibitor concentration was determined by fitting eq 4 (based on eq 3 ) to the data for the loss of MR activity as a function of time. The values of $k_{\text {obs }}$ were then plotted against the concentration of 3-HP to determine the efficiency of inactivation $\left(k_{\text {inact }} / K_{\mathrm{I}}\right.$ ) using eq 6 (based on eq 5 , because $\left.[3-\mathrm{HP}] \ll K_{\mathrm{I}}\right)$. Because saturation was not observed, only the apparent second-order rate constant $\left(k_{2}\right.$ or $k_{\text {inact }} / K_{\mathrm{I}}$ ) could be determined.

$$
\begin{aligned}
& \underline{y_{1}} \equiv \mathrm{e}^{-\mathrm{r}_{\mathrm{d}} \mathrm{t}^{t}} \\
& v_{b} \\
& \ln (\% \text { activity })=4.605-k_{\text {ods }} t(4) \\
& k_{\text {obs }}=\frac{k_{\text {inact }}[3-\mathrm{HP}]}{K_{\mathrm{l}}+[3-\mathrm{HP}]} \\
& k_{\text {obs }} \approx \frac{k_{\text {inact }}[3-\mathrm{HP}]}{K_{\mathrm{I}}}=k_{2}[3-\mathrm{HP}]
\end{aligned}
$$

MR (32.7 nM) that had been completely inactivated by 3-HP (15.95 $\mu \mathrm{M}$ ) was dialyzed for 4.5 and $10.5 \mathrm{~h}$ at $4{ }^{\circ} \mathrm{C}$ against HEPES assay buffer ( $\mathrm{pH}$ 7.5) to test the reversibility of the inhibition. After dialysis, no significant MR activity was regained relative to that of a control sample containing wild-type MR in the absence of 3-HP.

\section{Inactivation of MR by 3-HP in the Presence of Benzohydroxamate $(\mathrm{BzH})$}

MR (32.71 nM) was incubated with 3-HP (15.95 $\mu \mathrm{M})$ in the presence $B S A[0.05 \%(w / v)]$ and various concentrations of $\mathrm{BzH}(0,5$, 
10 , and $20 \mu \mathrm{M})$ at $25^{\circ} \mathrm{C}$. At various time points $(0,6,12,18$, and 24 $\mathrm{min})$, an aliquot $(200 \mu \mathrm{L})$ of the reaction mixture was added to the assay solution (total volume of $2.0 \mathrm{~mL}$ ) containing $(R)$-mandelate (final concentration of $10 \mathrm{mM}$ ) to determine the amount of MR activity remaining as described above. The observed pseudo-first-order rate constants for the inactivation of MR ( $\left.k_{\text {obs }}\right)$ by $3-\mathrm{HP}(15.95 \mu \mathrm{M})$ in the presence of various concentrations of $\mathrm{BzH}$ were determined by fitting eq 4 to the data for loss of MR activity as a function of time.

\section{Mass Spectrometry Analysis of MR Inactivated by 3-HP}

Wild-type MR $(0.7 \mathrm{mg} / \mathrm{mL})$ and H297N MR $(0.98 \mathrm{mg} / \mathrm{mL})$ were incubated with $3-\mathrm{HP}(4.0 \mathrm{mM})$ at $25^{\circ} \mathrm{C}$ until the activity of wild-type MR was undetectable using the CD-based assay [assay concentrations of $\mathrm{MR}$ and $(R)$-mandelate of $327 \mathrm{nM}$ and $10 \mathrm{mM}$, respectively]. A control sample containing wild-type MR was incubated for the same time period in the absence of 3-HP. After complete inactivation of wildtype MR by $3-\mathrm{HP}$, an aliquot ( $20 \mu \mathrm{L})$ was removed from each reaction mixture and subjected to SDS-PAGE (12\%).

\section{In-Gel Digestions}

Gel bands from SDS-PAGE corresponding to MR and H297N MR were excised from the gel and rinsed with deionized water $(2 \times 300$ $\mu \mathrm{L})$. The excised gel strips were then cut into cubes $\left(\sim 1 \mathrm{~mm}^{3}\right)$ and processed using an automated system for conducting in-gel protein digestions (Investigator Progest, Genomic Solutions). Briefly, the protein in the gel cubes was reduced using dithiothreitol $(10 \mathrm{mM})$, carboxamidomethylated using iodoacetamide $(100 \mathrm{mM})$, and digested for $12 \mathrm{~h}$ at $37^{\circ} \mathrm{C}$ using sequencing-grade trypsin (Promega). The peptides were extracted from the gel pieces by three 20 min incubations with a solution $(30 \mu \mathrm{L})$ containing acetonitrile $(50 \%)$ and formic acid (5\%) in LC-MS-grade water with gentle agitation. The extracts were pooled and dried using a vacuum concentrator (Speed Vac Concentrator, SPD 111 V-230, Thermo Electron Corp.) and finally resuspended in LC-MS-grade water $(15 \mu \mathrm{L})$ containing acetonitrile (3\%) and formic acid (0.5\%).

Biochemistry, Vol 54, No. 17 (May 5, 2015): pg. 2747-2757. DOI. This article is (C) American Chemical Society and permission has been granted for this version to appear in e-Publications@Marquette. American Chemical Society does not grant permission for this article to be further copied/distributed or hosted elsewhere without the express permission from American Chemical Society. 
NOT THE PUBLISHED VERSION; this is the author's final, peer-reviewed manuscript. The published version may be accessed by following the link in the citation at the bottom of the page.

\section{LC-ESI-MS/MS and Data Analysis}

LC-ESI-MS/MS was conducted using a nanoflow HPLC system (UltiMate 3000, Dionex) connected to a hybrid ion trap-orbitrap highresolution tandem mass spectrometer (Velos Pro, Thermo Scientific) operated in data-dependent acquisition (DDA) mode. Each sample (1 $\mu \mathrm{L}$ ) was injected onto a capillary column (C18 Onyx Monolithic, 0.10 $\mathrm{mm} \times 150 \mathrm{~mm}$, Phenomenex) at a flow rate of $300 \mathrm{~nL} / \mathrm{min}$. Samples were sprayed at $1.6 \mathrm{kV}$ using fused silica noncoated emitters (20 $\mathrm{\mu m}$ inside diameter with a $10 \mu \mathrm{m}$ ID tip, PicoTip Emitter from New Objective). Chromatographic separation was achieved using a linear gradient from 3 to $35 \%$ solvent $B$ in solvent A over 30 min and then increasing the level of solvent $B$ to $95 \%$ over 5 min (solvent $A$ consisted of $0.1 \%$ formic acid in water and solvent $B 0.1 \%$ formic acid in acetonitrile). The raw data files were acquired (Xcalibur, Thermo Fisher) and exported to Proteome Discoverer software version 1.4 (Thermo Fisher) for peptide and protein identification using the Sequest database search algorithm. ${ }^{27}$ Carbamidomethyl cysteine and oxidized methionines were selected as static and dynamic modifications, respectively. Peptide to spectrum match (PSM) validation was conducted using high-confidence XCorr threshold values of $1.9,2.3$, and 2.6 for doubly, triply, and more highly charged precursors.

\section{Analysis of H297N MR-3-HP Reduced with $\mathrm{NaCNBH}_{3}$}

H297N MR (0.98 mg/mL) was incubated with 3-HP $(4.0 \mathrm{mM})$ in assay buffer at $25^{\circ} \mathrm{C}$ for $30 \mathrm{~min}$. Sodium cyanoborohydride (10 $\mu \mathrm{L}$ of a $1 \mathrm{M}$ stock solution) was then added to the reaction mixture (total volume of $200 \mu \mathrm{L}$ ) to give a final concentration of $50 \mathrm{mM}$, and the $\mathrm{pH}$ was adjusted to 7.0 using $\mathrm{HCl}$. The reaction mixture was then incubated for an additional $30 \mathrm{~min}$. Finally, an aliquot of the reaction mixture $(20 \mu \mathrm{L})$ was subjected to SDS-PAGE (12\%) and analyzed using mass spectrometry as described above.

\section{X-ray Crystallography}

All crystals of wild-type MR were obtained at room temperature by the batch crystallization method. The protein solution consisted of

Biochemistry, Vol 54, No. 17 (May 5, 2015): pg. 2747-2757. DOI. This article is (C) American Chemical Society and permission has been granted for this version to appear in e-Publications@Marquette. American Chemical Society does not grant permission for this article to be further copied/distributed or hosted elsewhere without the express permission from American Chemical Society. 
MR $(6.0 \mathrm{mg} / \mathrm{mL})$ purified as described above, in the presence of $\mathrm{Na}^{+}-$ HEPES buffer (50 mM, pH 7.5) containing $\mathrm{MgCl}_{2}(3.3 \mathrm{mM})$ and 3-HP $(20 \mathrm{mM})$. The batch reservoir solution was composed of sodium acetate $(140 \mathrm{mM}, \mathrm{pH} 4.5), \mathrm{KCl}(280 \mathrm{mM})$, and pentaerythritol propoxylate 426 (PEP 426; 46\%). The protein solution and reservoir solution were gently mixed in a 1:1 ratio to a final volume of $20 \mu \mathrm{L}$, and $10 \mu \mathrm{L}$ of this mixture was pipetted into a lightly greased crystallization well and sealed with a glass coverslip lined with mineral oil. Crystals grew spontaneously for $17 \mathrm{~h}$, resulting in hexagonally shaped crystals. These crystals were looped directly from the wells to be flash-cooled in liquid nitrogen for storage.

\section{Data Collection, Structure Determination, and Refinement}

X-ray diffraction data for MR cocrystallized with 3-HP were collected at the Advanced Photon Source (APS) beamline LS-CAT-21ID-G on a Rayonix MarMosaic 300 CCD detector, with an X-ray wavelength of $0.979 \AA$. Diffraction images were processed using HKL2000. ${ }^{28}$ The structure was determined by molecular replacement using the wild-type MR enzyme [Protein Data Bank (PDB) 2MNR] as the search model with Phaser. ${ }^{29}$ The molecular replacement models were extended by several rounds of manual model building with $\mathrm{COOT}^{30}$ and refinement with REFMAC ${ }^{31}$ using an automatically generated geometric/X-ray weighting term. Water molecules were added to the model in COOT with subsequent manual verification. On the basis of protein purification conditions and the well-established metal binding preference of $\mathrm{MR}, \mathrm{a} \mathrm{Mg}^{2+}$ ion was modeled into the active site, despite the fact that a modeled $\mathrm{Mg}^{2+}$ ion does not satisfy all of the observed electron density at this position.

\section{Results and Discussion}

\section{Structure-Activity Study}

We examined the effect of the a-keto acids 3-HP, mesoxalate, 3-fluoropyruvate (3-FP), and pyruvate on MR activity (Chart 1). Mesoxalate, which is fully hydrated in water (i.e., C2 gem-diol), ${ }^{32}$ was a competitive inhibitor of MR with respect to $(R)$-mandelate $\left[K_{\mathrm{i}}=1.8\right.$ 
$\pm 0.3 \mathrm{mM}$ (Figure $1 \mathrm{~S}$ of the Supporting Information)], binding with the same affinity as tartronate $\left(K_{\mathrm{i}}=1.8 \mathrm{mM}\right){ }^{23}$ suggesting that the glycolate-like moiety present in both ligands chelates the $\mathrm{Mg}^{2+}$ and the second carboxylate forms a salt bridge with the active site Brønsted acid-base catalysts, thereby compensating for the loss of hydrophobic interactions. ${ }^{23}$ Pyruvate, which exists as the keto form under the assay conditions, ${ }^{33,34}$ exhibited only $40 \%$ inhibition of MR activity at a concentration of $25 \mathrm{mM}$ [i.e., $K_{\mathrm{i}} \approx 20 \mathrm{mM}$, assuming competitive inhibition with $1 \mathrm{mM}(R)$-mandelate; $K_{\mathrm{m}}=1.2 \mathrm{mM}$ ]. This low binding affinity is similar to that of lactate $\left(K_{\mathrm{i}} \approx 30 \mathrm{mM}\right)^{20}$ and likely arises because the methyl group is not sufficiently hydrophobic, nor can it form salt bridges with the Brønsted acid-base catalysts. MR bound 3FP with an affinity $\left[K_{\mathrm{i}}=1.3 \pm 0.1 \mathrm{mM}\right.$ (Figure $2 \mathrm{~S}$ of the Supporting Information)] $\sim 15$-fold greater than the affinity it exhibited for pyruvate, due to either dipolar interactions (rather than true $\mathrm{H}$ bonds) ${ }^{35,36}$ with the active site acid-base catalysts or enhanced hydrophobic interactions. ${ }^{37}$

In aqueous solutions, a-keto acids can exist as hydrates (gemdiols) to varying degrees. ${ }^{33}$ The hydration state will determine the hybridization of $\mathrm{C} 2$ and could affect the binding of a-keto acids at the active site of MR. Pyruvate exists as the keto form (>92\%) at pH $6.8,^{33,34}$ and benzoylformate (an a-keto acid examined previously) ${ }^{38}$ is also expected to be in the keto form $(>90 \%)$ at the assay pH. ${ }^{39}$ Our observations that MR binds pyruvate $\left(K_{\mathrm{i}} \sim 20 \mathrm{mM}\right)$ and benzoylformate $\left(K_{\mathrm{i}}=0.65 \mathrm{mM}\right)^{38}$ with affinities similar to those for lactate $\left(K_{\mathrm{i}}=30\right.$ $\mathrm{mM})^{20}$ and $(R)$-mandelate $\left(K_{\mathrm{m}}=0.81 \mathrm{mM}\right){ }^{38}$ respectively, suggest that the enzyme does not distinguish between $\mathrm{sp}^{2}$ and $\mathrm{sp}^{3}$ hybridization at C2 in the ground state. Mesoxalate and 3-FP are $100 \%$ and $>90 \%$ hydrated, respectively, in aqueous solutions. ${ }^{32,40-42}$ However, in the active site of $M R$, it is possible that coordination of the metal ion could lead to dehydration of the gem-diols, yielding the corresponding keto species. ${ }^{43}$ It is unlikely, however, that this latter possibility would result in a significant alteration of the binding affinity considering our observations with pyruvate and lactate, and benzoylformate and mandelate, mentioned above. 
NOT THE PUBLISHED VERSION; this is the author's final, peer-reviewed manuscript. The published version may be accessed by following the link in the citation at the bottom of the page.

\section{Inactivation by 3-HP}

Surprisingly, 3-HP $(8.0 \mu \mathrm{M})$ showed time-dependent inhibition, while the other a-keto acids did not show such behavior at a concentration of $10 \mu \mathrm{M}$ (Figure 1a) or $2 \mathrm{mM}$ (Figure $3 \mathrm{~S}$ of the Supporting Information). Dialysis of the inactive 3-HP-treated MR against assay buffer for $\sim 11 \mathrm{~h}$ did not restore enzymatic activity, indicating that the inactivation was irreversible. The inactivation of MR by 3-HP followed pseudo-first-order kinetics (Figure 1b), and the observed pseudo-first-order rate constants $\left(k_{\text {obs }}\right)$ exhibited a linear dependence on the concentration of 3-HP (Figure 1c). Saturation was not observed at 3-HP concentrations of $\leq 16 \mu \mathrm{M}$, and at higher concentrations of $3-\mathrm{HP}$, we were not able to obtain accurate $k_{\text {obs }}$ values because the loss of the MR activity was too rapid (relative to the assay duration of $3 \mathrm{~min}$ ). Consequently, we were not able to differentiate between a kinetic mechanism for inactivation following a single step and a two-step mechanism with the reversible formation of a binary complex between MR and 3-HP. The slope from the plot of $k_{\text {obs }}$ versus the concentration of 3-HP gave an apparent second-order rate constant for inactivation ( $k_{\text {inact }} / K_{\mathrm{I}}$ or $k_{2}$ ) with a value of $83 \pm 8 \mathrm{M}^{-1} \mathrm{~s}^{-1}$. The observed rate of inactivation by $3-\mathrm{HP}$ was reduced in the presence of the reversible competitive inhibitor benzohydroxamate $(\mathrm{BzH})$

(Figure 1d), indicating that 3-HP likely binds at the active site.
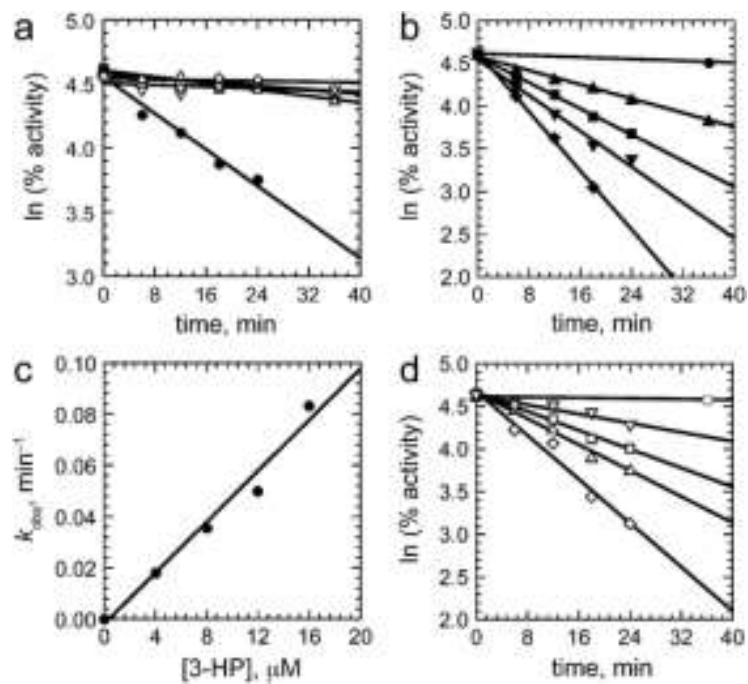

Figure 1. Time-dependent inhibition of MR activity. (a) Time-dependent inactivation of MR (32.7 nM) incubated with either 3-HP $(8.0 \mu \mathrm{M}, \bullet)$, mesoxalate $(10 \mu \mathrm{M}, \nabla)$, pyruvate $(10 \mu \mathrm{M}, \square)$, benzoylformate $(10 \mu \mathrm{M}, \Delta)$, 3-FP $(10 \mu \mathrm{M}, \diamond)$, or no inhibitor (o)

Biochemistry, Vol 54, No. 17 (May 5, 2015): pg. 2747-2757. DOI. This article is (C) American Chemical Society and permission has been granted for this version to appear in e-Publications@Marquette. American Chemical Society does not grant permission for this article to be further copied/distributed or hosted elsewhere without the express permission from American Chemical Society. 
NOT THE PUBLISHED VERSION; this is the author's final, peer-reviewed manuscript. The published version may be accessed by following the link in the citation at the bottom of the page.

at $25^{\circ} \mathrm{C}$. The reaction mixture was diluted 10 -fold by addition of assay buffer containing $(R)$-mandelate (final concentration of $10 \mathrm{mM}$ ), and the initial rates were measured at the indicated times. (b) Time-dependent inactivation of MR (32.7 nM) incubated with various concentrations of 3-HP: $0(\bullet), 4.0(\boldsymbol{\Delta}), 8.0(\boldsymbol{\bullet}), 12.0(\boldsymbol{\nabla})$, and $16.0(\diamond) \mu \mathrm{M}$ at $25^{\circ} \mathrm{C}$. The initial rates were measured at the indicated time points. (c) Observed pseudo-first-order rate constants for inactivation $\left(k_{\mathrm{obs}}\right)$ plotted as a function of 3-HP concentration. The slope yields a value for the apparent second-order rate constant for the efficiency of inactivation $\left(k_{\text {inact }} / K_{\mathrm{I}}\right)$ equal to $83 \pm 8 \mathrm{M}^{-1} \mathrm{~s}^{-1}$. (d) Protection against 3-HP-dependent inactivation of MR by $0(\diamond), 5(\Delta), 10(\square)$, and 20 $(\nabla) \mu \mathrm{M}$ benzohydroxamate at $25^{\circ} \mathrm{C}$. MR was incubated with $3-\mathrm{HP}(16.0 \mu \mathrm{M})$, and the initial rates were measured at the indicated time points as described above. The value for the control reaction, in the absence of 3-HP, is also shown ( 0 ). Experimental details may be found in Materials and Methods.

\section{Site of Covalent Modification}

To identify the residue(s) modified upon inactivation by 3-HP, 3HP-modified MR (3-HP-MR) and an untreated sample of MR (control$M R$ ) were subjected to SDS-PAGE followed by in-gel digestion with trypsin. The resulting proteolytic cleavage peptides were analyzed using LC-ESI-MS/MS. For both control-MR and 3-HP-MR, $\geq 95 \%$ sequence coverage was obtained. MS data showed identical peptides in both the control-MR and 3-HP-MR samples with the exception of the cleavage fragment TKIGYPALDQDLAVVR (TK-peptide, residues 165180 with one missed cleavage site). The TK-peptide in the 3-HP-MR sample gave two $\mathrm{m} / \mathrm{z}$ peaks. One peak corresponded to an unmodified peptide $\left(\mathrm{MH}^{+}, \mathrm{m} / z\right.$ 1758.97) that was also observed in control-MR, suggesting that either the enzyme was partially modified or some modification was reversed during sample preparation. The other TKpeptide had a higher $\mathrm{m} / \mathrm{z}$ value $\left(\mathrm{MH}^{+}, \mathrm{m} / \mathrm{z}\right.$ 1844.98), consistent with MR being modified by addition of a group with a mass of $86 \mathrm{Da}$. Internal fragmentation of the triply charged modified TK-peptide (monoisotopic, $m / z 615.66$ ) and the triply charged unmodified TKpeptide (monoisotopic, $m / z$ 586.99) precursors gave a mass increment of $86 \mathrm{Da}$ between the $\mathrm{b}_{2}{ }^{+}$ions arising from the modified (316.34 Da) and unmodified (230.27 Da) TK-peptides, suggesting modification of either Thr 165 or Lys 166 (Figure 2a,b). Modification of Thr 165 seemed unlikely because the side chain of this residue is directed away from the active site, and it is difficult to account for the increment of $86 \mathrm{Da}$. The remaining $\mathrm{b}$ and $\mathrm{y}$ ions corresponded to the expected amino acid sequence of the TK-peptides. Upon treatment of H297N MR with 3-HP and subsequent LC-ESI-MS/MS analysis, no modified tryptic peptides were observed, suggesting that His 297 is required for

Biochemistry, Vol 54, No. 17 (May 5, 2015): pg. 2747-2757. DOI. This article is (C) American Chemical Society and permission has been granted for this version to appear in e-Publications@Marquette. American Chemical Society does not grant permission for this article to be further copied/distributed or hosted elsewhere without the express permission from American Chemical Society. 
NOT THE PUBLISHED VERSION; this is the author's final, peer-reviewed manuscript. The published version may be accessed by following the link in the citation at the bottom of the page.

irreversible inhibition. Thus, our kinetic and MS/MS results suggest that 3-HP modifies Lys 166, with the resulting adduct having a molecular mass of 86 Da.

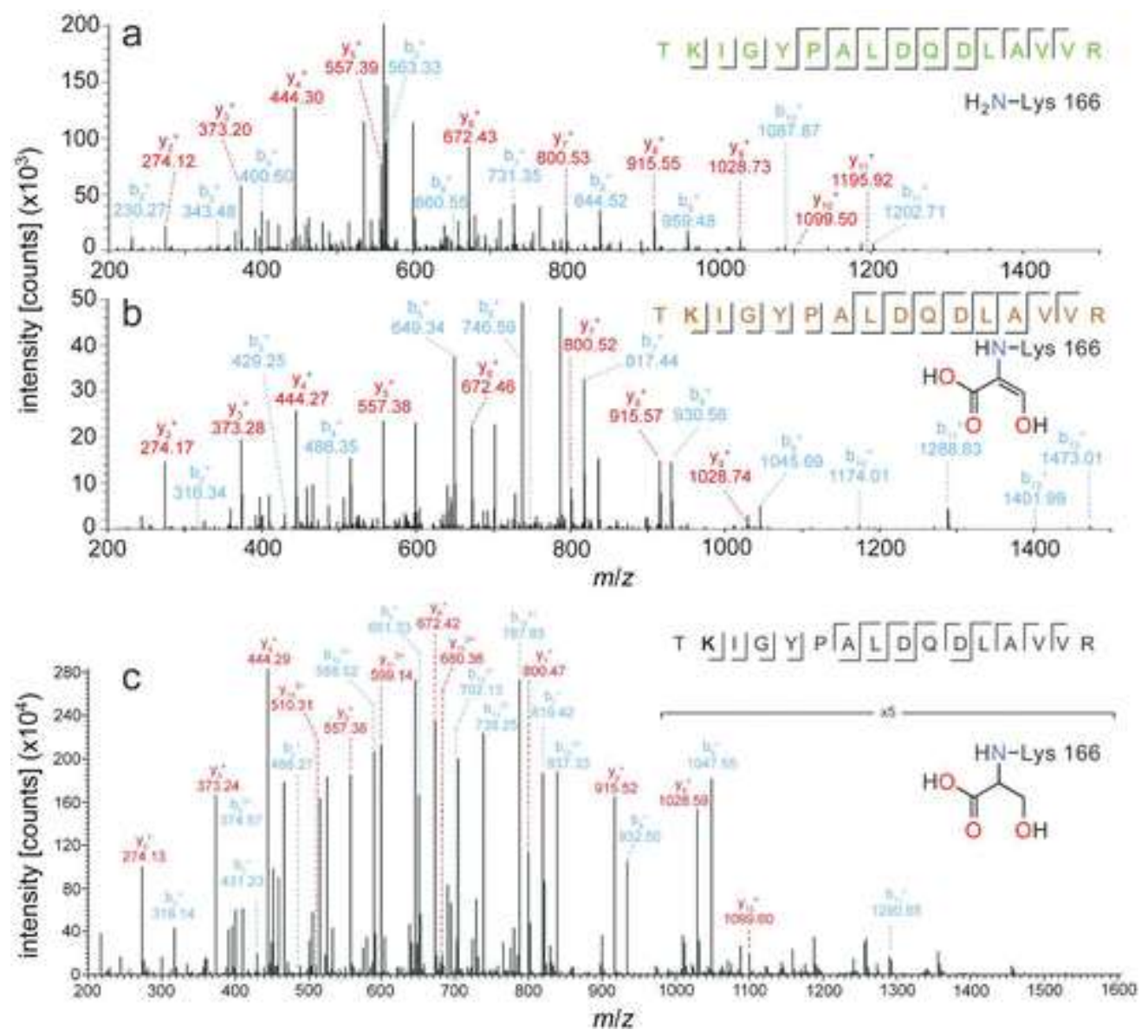

Figure 2. ESI-MS/MS analysis of TK-peptides. Mass spectra for the triply charged ion of the TK-peptide from (a) untreated wild-type MR $\left(\mathrm{m} / z\right.$ 586.995; $\mathrm{MH}^{+}=1758.971$ $\mathrm{Da})$ and (b) 3-HP-treated wild-type $\mathrm{MR}\left(\mathrm{m} / \mathrm{z} 615.664 ; \mathrm{MH}^{+}=1844.976 \mathrm{Da}\right)$ reveal modification of the tryptic peptide (with one missed cleavage site), increasing the mass by $86 \mathrm{Da}$. The increase in mass of the $\mathrm{b}_{2}{ }^{+}$ion by $86 \mathrm{Da}$ suggests modification of Lys 166 (bold in panel b). (c) ESI-MS/MS analysis of the triply charged ion ( $\mathrm{m} / \mathrm{z}$ $616.329 ; \mathrm{MH}^{+}=1846.97 \mathrm{Da}$ ) of the TK-peptide (residues 165-180) arising from the trypsin-digested 3-HP-modified $\mathrm{H} 297 \mathrm{~N}$ MR treated with $\mathrm{NaCNBH}_{3}$ reveals modification of the active site Lys 166 , increasing the mass by $88 \mathrm{Da}$. This mass is consistent with reduction of the Schiff-base adduct.

\section{Mechanism of Inactivation}

A possible mechanism accounting for our observations involves the reversible formation of a Schiff base (imine) between the $\varepsilon-\mathrm{NH}_{2}$ group of Lys 166 and the a-carbonyl of 3-HP [C2 mechanism (Scheme

Biochemistry, Vol 54, No. 17 (May 5, 2015): pg. 2747-2757. DOI. This article is (C) American Chemical Society and permission has been granted for this version to appear in e-Publications@Marquette. American Chemical Society does not grant permission for this article to be further copied/distributed or hosted elsewhere without the express permission from American Chemical Society. 
2)], similar to the mechanism proposed for the inactivation of $\mathrm{N}$ acetylneuraminate lyase (NAL) ${ }^{44}$ and dihydrodipicolinate synthase (DHDPS $)^{45}$ by 3 -HP. Subsequent deprotonation of the Schiff base (presumably by His 297) would yield an enol or enolate [i.e., enol(ate)] (86 Da), which could tautomerize to yield a covalent aldehyde adduct. Incubation of H297N MR with 3-HP, followed by treatment with $\mathrm{NaCNBH}_{3}$, and subsequent separation by SDS-PAGE and analysis using LC-ESI-MS/MS revealed that Lys 166 of the TKpeptide was modified by a group with a mass of $88 \mathrm{Da}$ (Figure 2c), consistent with reduction of the Schiff base and in accord with the proposed inactivation mechanism. In addition, we observed two $88 \mathrm{Da}$ adducts arising from the nonspecific modification of Lys 207 and Lys 238 located away from the dimer interface on the surface of the enzyme (data not shown). Such adducts would be expected considering that imines may form spontaneously at other sites bearing a primary amino group. ${ }^{46,47}$

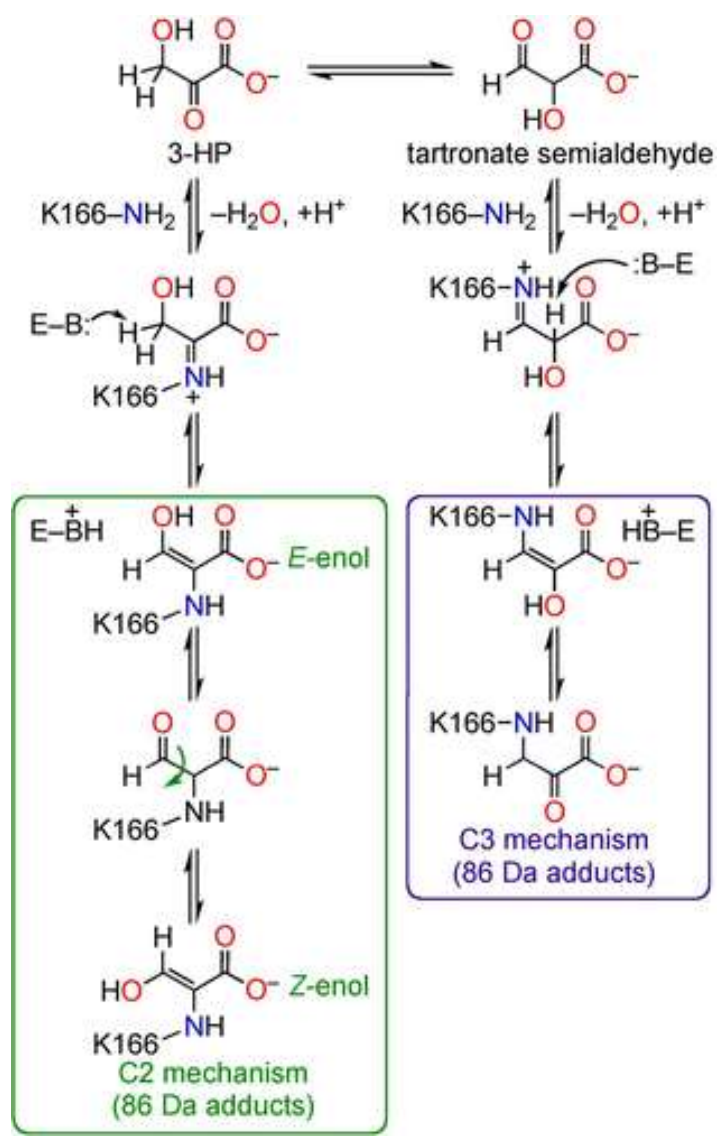

Scheme 2. Proposed Mechanisms for Inactivation of MR by 3-HP Giving Rise to an 86 Da Adduct

Biochemistry, Vol 54, No. 17 (May 5, 2015): pg. 2747-2757. DOI. This article is (C) American Chemical Society and permission has been granted for this version to appear in e-Publications@Marquette. American Chemical Society does not grant permission for this article to be further copied/distributed or hosted elsewhere without the express permission from American Chemical Society. 
Alternatively, 3-HP may undergo tautomerization either in solution or within the active site to yield tartronate semialdehyde. ${ }^{48}$ Schiff-base formation between Lys 166 and the aldehyde [C3 mechanism (Scheme 2)], followed by deprotonation, also yields an adduct with a mass of $86 \mathrm{Da}$ and is consistent with our LC-ESI-MS/MS observations.

\section{Structural Studies}

To distinguish between these two mechanistic possibilities, we determined the X-ray crystal structure of MR inactivated by 3-HP at $1.65 \AA$ resolution (Table 1 ). The electron density clearly indicates bond formation occurs between the $\varepsilon-\mathrm{NH}_{2}$ group of Lys 166 and $\mathrm{C} 2$ of 3-HP in accord with the C2 mechanism (Figure 3 and Figure $4 \mathrm{~S}$ of the Supporting Information). The structure was refined by defining a single bond between the $\varepsilon-\mathrm{NH}_{2}$ group of Lys 166 and $\mathrm{C} 2$ of 3-HP, and the 3$\mathrm{HP}$ adduct was further refined in two alternative conformations: major $(70 \%)$ and minor (30\%) conformations of either the $(E)$-enol(ate) or the aldehyde. Although it is not possible to determine whether the product adduct exists as the aldehyde or enol(ate) tautomer from the crystal structure, the enol(ate) may be preferred because enolase, which has a similar active site architecture, is strongly inhibited by the enolate of d-tartronate semialdehyde phosphate. ${ }^{49,50}$ Certainly, the active site of MR is optimized to stabilize an enolate in accord with its ability to catalyze racemization, and $\mathrm{N} \varepsilon 2$ of His 297 is $2.9 \AA$ from the terminal oxygen of the major adduct so that it is capable of stabilizing the enol(ate) through $\mathrm{H}$-bonding (Figure 3 ). The inability of 3-FP to inactivate $M R$ indicates that the formation of either the enol(ate) or aldehyde by $3-\mathrm{HP}$ is essential for inactivation. 
NOT THE PUBLISHED VERSION; this is the author's final, peer-reviewed manuscript. The published version may be accessed by following the link in the citation at the bottom of the page.

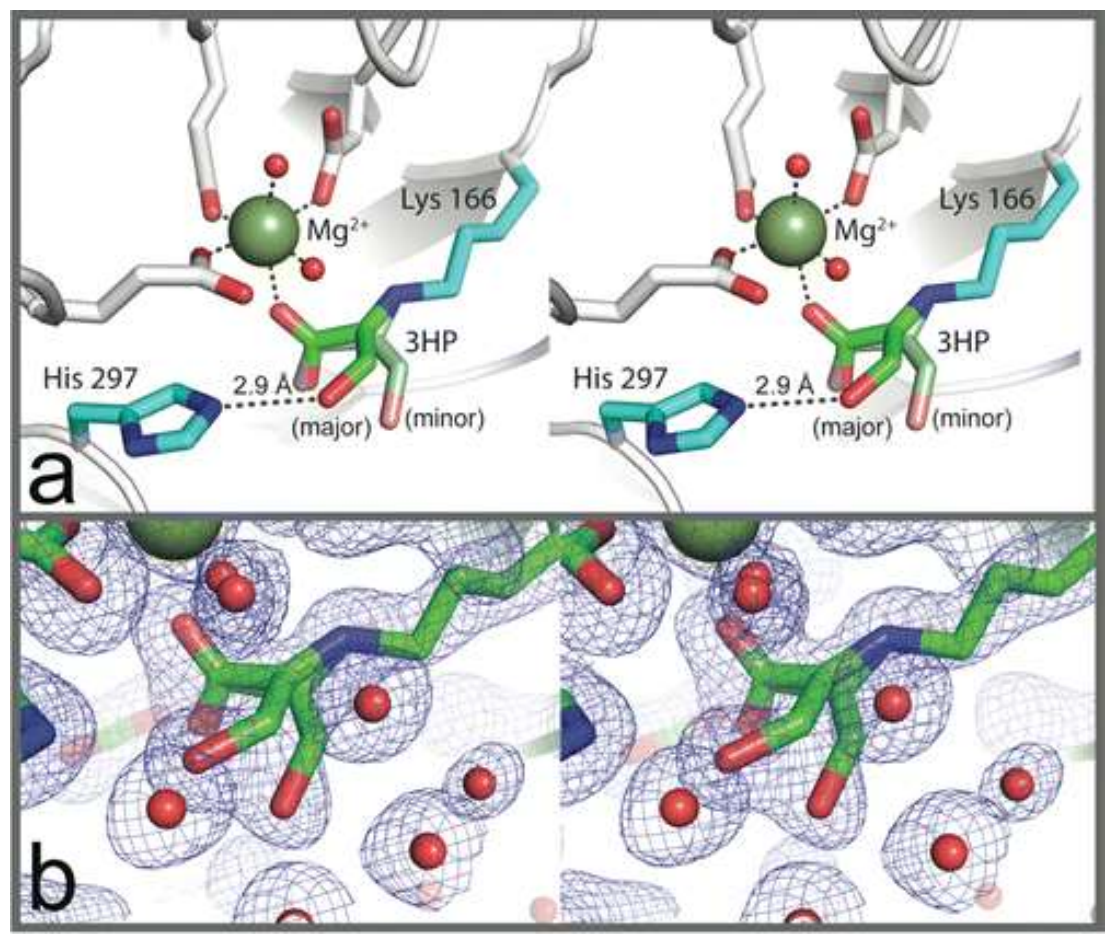

Figure 3. X-ray structure of 3-HP-MR. (a) Stereoview of the active site showing the major (70\%) and minor (30\%) conformations of the 3-HP adduct with Lys 166 . The aldehyde/enol(ate) oxygen of the major conformation is within $\mathrm{H}$-bonding distance of the Brønsted acid-base catalyst His 297. (b) Stereoview of representative $2 F_{0}-F_{c}$ electron density maps, contoured at $1.0 \sigma$, for the 3-HP-MR structure showing a closeup view of the Lys 166-3-HP adduct.

Table 1. X-ray Data Collection and Refinement Statistics

\section{3-HP-MR}

PDB entry

space group

cell dimensions

$a, b, c(\AA)$

a, $\beta, y($ deg $)$

resolution range $(\AA)$

redundancy

completeness (\%)

no. of unique reflections

$R_{\text {merge }}$

average $I / \sigma$

resolution range $(\AA)$

$R_{\text {cryst }}$

$R_{\text {free }}$

no. of protein atoms
$4 \times 2 P$

I422

$123.88,123.88,105.30$

$90,90,90$

$50.0-1.65(1.68-1.65)^{a}$

$13.0(8.4)^{a}$

$99.6(94.0)^{a}$

49040

$0.082(0.437)^{a}$

$29.55(4.125)^{a}$

Refinement

$40-1.65(1.69-1.65)^{a}$

$0.145(0.181)^{a}$

$0.177(0.232)^{a}$

2757

Biochemistry, Vol 54, No. 17 (May 5, 2015): pg. 2747-2757. DOI. This article is (C) American Chemical Society and permission has been granted for this version to appear in e-Publications@Marquette. American Chemical Society does not grant permission for this article to be further copied/distributed or hosted elsewhere without the express permission from American Chemical Society. 


$\begin{array}{lc}\text { no. of water molecules } & 297 \\ \text { Wilson } B \text { value }\left(\AA^{2}\right) & 17.0 \\ \text { average } B \text { factor }\left(\AA^{2}\right) & \\ \text { protein } & 16.1 \\ \text { ligand } & 23.9 \\ \text { Mg2+ } & 2.3 \\ \text { solvent } & 26.1 \\ \text { Ramachandran plot (\%) } & \\ \text { most favored } & 91.5 \\ \text { additionally allowed } & 7.5 \\ \text { generously allowed } & 0.7 \\ \text { disallowed } & 0.3 \\ \text { root-mean-square deviations } & \\ \text { bond lengths }(\AA) & 0.028 \\ \text { bond angles (deg) } & 2.54 \\ \text { aValues in parentheses are for the highest-resolution bin. }\end{array}$

no. of water molecules

Wilson $B$ value $\left(\AA^{2}\right)$

ligand

solvent

Ramachandran plot (\%)

most favored

91.5

7.5

0.028

C2 of the 3-HP enamine occupies a position approximately equivalent to that of the a-methyl group of (S)-atrolactate (Figure 4). Both ground state and transition state analogues bind to MR with one carboxylate oxygen and the a-OH group coordinated to $\mathrm{Mg}^{2+}$ in the active site. In the 3-HP-MR structure, however, the a-OH group is replaced with a free water molecule, while one carboxylate oxygen maintains coordination with $\mathrm{Mg}^{2+}$ in a manner analogous to that of the substrate and transition state analogues. This coordination with the active site $\mathrm{Mg}^{2+}$ likely facilitates deprotonation of the Schiff base by His 297, similar to its role in stabilizing the aci-carboxylate intermediate during the racemization of mandelate. Interestingly, the active site lid (20s loop) that typically closes over the active site when either ground state or transition state analogues are bound adopts an "open" conformation in the 3-HP-MR structure (Figure 5). This conformation may arise because the hydrophobic group (i.e., aromatic ring) present on substrates and intermediate analogues is not present to drive lid closure. ${ }^{51}$ The 20 s loop in the structure of MR (PDB entry 4M6U) with bound tartronate, which also lacks the phenyl ring, exhibited an approximately $1: 1$ ratio of both the open and closed conformations; ${ }^{23}$ however, it is important to note that the 20s loop of MR with only sulfate bound (PDB entry 2MNR) was closed, suggesting that other factors may also contribute to the observed conformation of the loop in crystals. ${ }^{8}$

Biochemistry, Vol 54, No. 17 (May 5, 2015): pg. 2747-2757. DOI. This article is (C) American Chemical Society and permission has been granted for this version to appear in e-Publications@Marquette. American Chemical Society does not grant permission for this article to be further copied/distributed or hosted elsewhere without the express permission from American Chemical Society. 


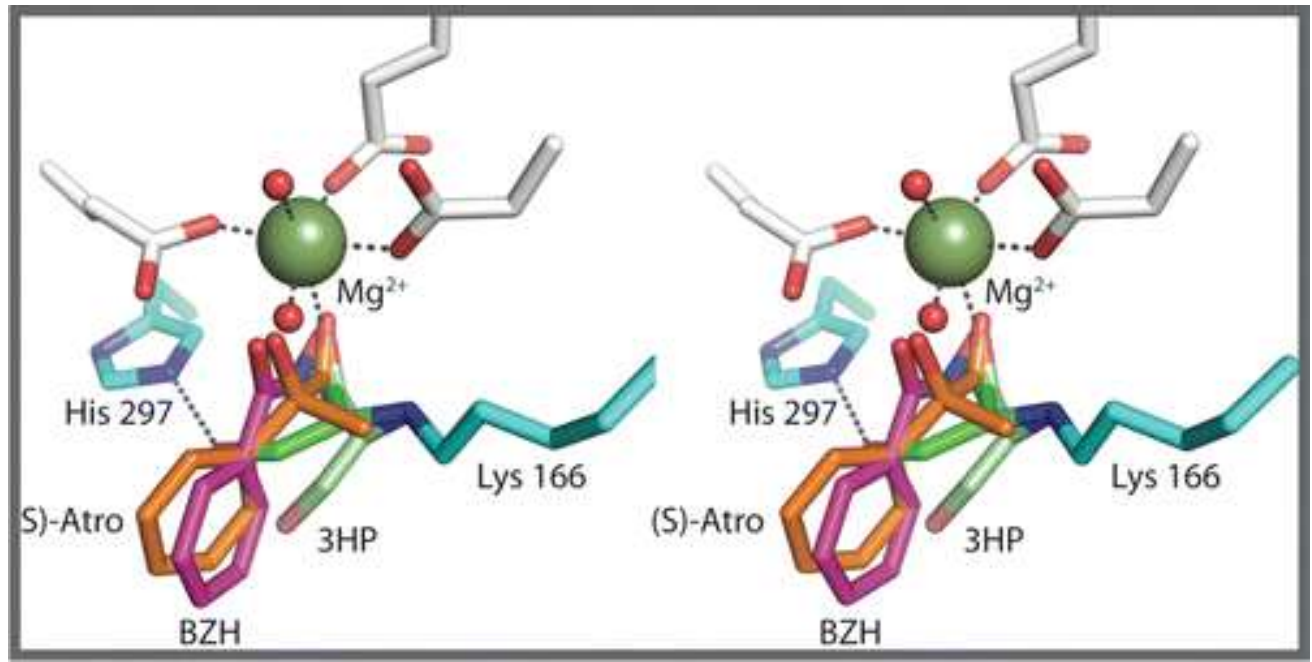

Figure 4. Stereoview of the active site of MR containing the adduct with 3-HP (green), overlaid with the bound substrate analogue $(S)$-atrolactate [(S)-Atro; PDB entry $1 \mathrm{MDR}$, orange $],(71)$ and the intermediate analogue benzohydroxamate (BzH; PDB entry 3UXK, pink).(72) The Brønsted acid-base catalysts (His 297 and Lys 166) are colored cyan.

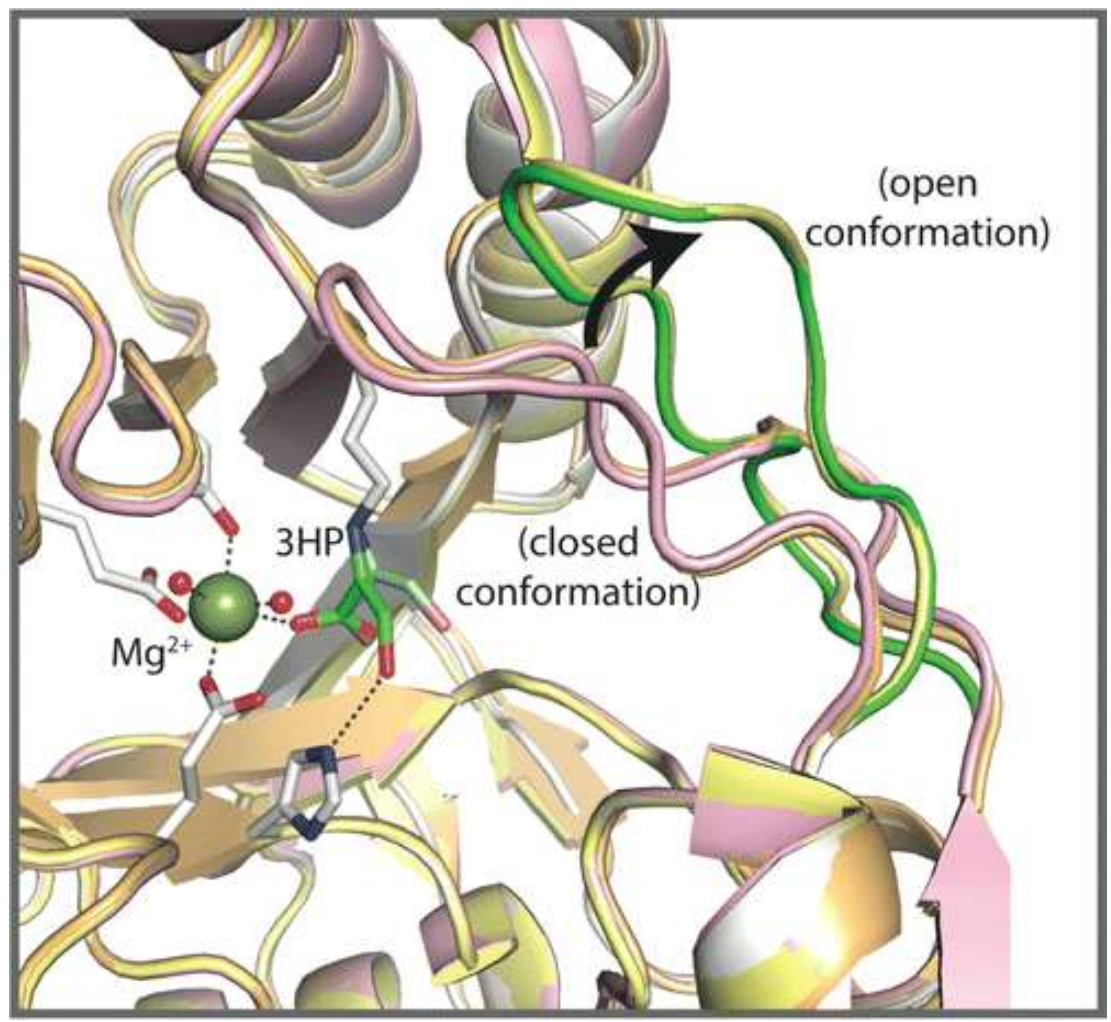

Figure 5. Structural overlay of the 3-HP-MR structure (colored white, with the 20s loop colored green) with the structures of MR in the presence of $(S)$-atrolactate (PDB entry $1 \mathrm{MDR}$, orange), ${ }^{71}$ benzohydroxamate (PDB entry $3 \mathrm{UXK}$, pink), ${ }^{72}$ and benzilate

Biochemistry, Vol 54, No. 17 (May 5, 2015): pg. 2747-2757. DOI. This article is (C) American Chemical Society and permission has been granted for this version to appear in e-Publications@Marquette. Ame rican Chemical Society does not grant permission for this article to be further copied/distributed or hosted elsewhere without the express permission from American Chemical Society. 
NOT THE PUBLISHED VERSION; this is the author's final, peer-reviewed manuscript. The published version may be accessed by following the link in the citation at the bottom of the page.

(PDB entry 4HNC, yellow). ${ }^{23}$ Aside from 3-HP, all other ligands are not shown for the sake of clarity. The 3-HP-MR structure exhibits an "open" conformation of the 20s loop lid, similar to the conformation observed when the bulky substrate-product analogue benzilate is bound to C92S/C264S/K166C MR. ${ }^{23}$

\section{Mechanistic Link between Superfamilies}

The formation of a Schiff base is unprecedented in the enolase superfamily. However, irreversible inhibition by 3 -HP has been demonstrated for members of the NAL superfamily. This superfamily includes NAL, DHDPS, trans-o-hydroxybenzylidene-pyruvate hydratase-aldolase, and d-4-deoxy-5-oxoglucarate dehydratase, $, 2,7,52$ which have also been included within the class I aldolases ${ }^{53}$ by the SCOP database ${ }^{54,55}$ on the basis of their similar Schiff-base chemistry and common $(a / \beta)_{8}$-fold. 3-HP inactivates NAL from Clostridium fringens $^{56}$ and E. coli ${ }^{44}$ and DHDPS from E. coli, ${ }^{45}$ and the X-ray crystal structures of the covalently modified NAL and DHDPS enzymes revealed the presence of an aldehyde/enol(ate)-lysine adduct similar to the one we observe for MR inactivated by $3-\mathrm{HP} .{ }^{44,45}$ Although the mechanism-based inhibition of these two NAL superfamily members by 3-HP also proceeds via initial Schiff-base formation followed by deprotonation, ${ }^{44,45}$ the apparent second-order rate constant for the inactivation of MR exceeds that observed for inactivation of DHDPS $\left(0.56 \mathrm{M}^{-1} \mathrm{~s}^{-1}\right)$ by $\sim 138$-fold. This observation is in accord with the active site of MR being optimized to promote enolate formation.

Many of the enzymes sharing the highly prevalent $(a / \beta)_{8}$-barrel (or TIM barrel) folding topology 53,57-62 are believed to have arisen via divergent evolution from a common ancestor or a limited number of progenitor enzymes. ${ }^{53,60,63-67}$ Many aldolases share this fold with members of the enolase and NAL superfamilies, as well as sharing a similar mechanistic theme, i.e., the formation of a "masked" carbanionic intermediate (Scheme 3). Formation of such an intermediate is facilitated via formation of an imine/enamine "electron sink" with an active site lysine residue in the class I aldolases, and by utilizing a transition metal ion (usually $\mathrm{Zn}^{2+}$ ) as an essential Lewis acid cofactor in the class II aldolases. Although the reaction mechanisms differ between these two classes of aldolases, their ancestral aldolase has been postulated to have been a Schiff-base-forming enzyme that subsequently gave rise to a lineage of metal-dependent class II 
aldolases. ${ }^{53}$ Several comparisons of sequences, structures, and functions have suggested common ancestry between the class I and II aldolases and the enolase superfamily. 53,57,63,67 Considering the metal ion dependence of the class II aldolases, the mechanistic link to the enolase superfamily was clear (Scheme 3), 68 but such a link between the class I aldolases and the enolase superfamily was not evident. Allen and co-workers conducted a comparison of the primary and tertiary structures of class I aldolases and members of the NAL superfamily, and concluded that these enzymes could all be included in a large superfamily utilizing Schiff-base chemistry and related by divergent evolution from a common progenitor enzyme. ${ }^{69}$ Interestingly, these authors employed MR as a "negative control" because it was deemed not to be mechanistically related to the aldolases. This study suggests that a mechanistic relationship does indeed exist. Thus, while over evolutionary time scales the catalytic mechanism of enzymes may not be fully conserved, ${ }^{67}$ the ability of MR to form and deprotonate a Schiff-base intermediate furnishes a mechanistic link to other $a / \beta$-barrel enzymes utilizing Schiff-base chemistry and may be a relic of an activity possessed by a promiscuous progenitor enzyme. ${ }^{70}$ Delineating such chemistry-based relationships and their overlap with structure space and sequence space affords a more complete understanding of nature's strategies for the evolution of new catalysts. ${ }^{3}$

Enolase Superfamily<smiles>[Y16]OC([R])(O[Z10])C(=O)[O+][OH+]</smiles>

NAL Superfamily / Aldolase I

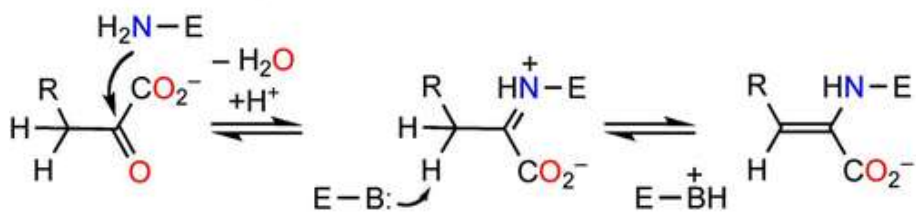

Aldolase II

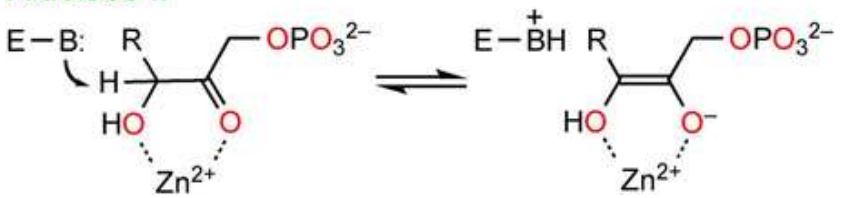

Scheme 3. Summary of the Reactions Catalyzed by the Enolase and NAL Superfamilies and the Class I and II Aldolases 
NOT THE PUBLISHED VERSION; this is the author's final, peer-reviewed manuscript. The published version may be accessed by following the link in the citation at the bottom of the page.

\section{Accession Codes}

The atomic coordinates of the 3-HP-MR structure have been deposited in the Protein Data Bank as entry 4X2P.

\section{Funding Information}

This work was supported by a Discovery Grant from the Natural Sciences and Engineering Research Council (NSERC) of Canada (S.L.B.) and National Science Foundation MRI-R2 Grant DBI-0959442 (M.St.M.). Use of the Advanced Photon Source was supported by U.S. Department of Energy, Office of Science, Office of Basic Energy Sciences, under Contract DE-AC02-06CH11357. Use of LS-CAT Sector 21 was supported by the Michigan Economic Development Corp. and the Michigan Technology Tri-Corridor for the support of this research program (Grant 085P1000817). B.N.W. was supported by a GAANN award (Graduate Assistance in Areas of National Need) from the U.S. Department of Education.

The authors declare no competing financial interest.

\section{Acknowledgment}

We thank Alejandro Cohen of the Dalhousie Faculty of Medicine Proteomics Core Facility for his assistance in conducting and analyzing LC-ESI-MS/MS data.

\section{Abbreviations}

$\begin{array}{ll}\text { BzH } & \text { benzohydroxamate } \\ \text { CD } & \text { circular dichroism } \\ \text { DHDPS } & \text { dihydrodipicolinate synthase } \\ \text { ESI } & \text { electrospray ionization } \\ \text { 3-FP } & \text { 3-fluoropyruvate } \\ \text { 3-HP } & \text { 3-hydroxypyruvate } \\ \text { 3-HP-MR } & \text { wild-type MR modified by 3-HP } \\ \text { LC } & \text { liquid chromatography } \\ \text { MR } & \text { mandelate racemase } \\ \text { MS } & \text { mass spectrometry }\end{array}$

Biochemistry, Vol 54, No. 17 (May 5, 2015): pg. 2747-2757. DOI. This article is (C) American Chemical Society and permission has been granted for this version to appear in e-Publications@Marquette. American Chemical Society does not grant permission for this article to be further copied/distributed or hosted elsewhere without the express permission from American Chemical Society. 
NOT THE PUBLISHED VERSION; this is the author's final, peer-reviewed manuscript. The published version may be accessed by following the link in the citation at the bottom of the page.

NAL $\quad N$-acetylneuraminate lyase

TFHTP 3,3,3-trifluoro-2-hydroxy-2-(trifluoromethyl)propanoate.

\section{References}

${ }^{1}$ Babbitt, P. C., Mrachko, G. T., Hasson, M. S., Huisman, G. W., Kolter, R., Ringe, D., Petsko, G. A., Kenyon, G. L., and Gerlt, J. A. ( 1995) A functionally diverse enzyme superfamily that abstracts the a protons of carboxylic acids Science 267, 1159- 1161

2 Babbitt, P. C. and Gerlt, J. A. (1997) Understanding enzyme superfamilies. Chemistry as the fundamental determinant in the evolution of new catalytic activities J. Biol. Chem. 272, 30591- 30594

${ }^{3}$ Gerlt, J. A. and Babbitt, P. C. (2001) Divergent evolution of enzymatic function: Mechanistically diverse superfamilies and functionally distinct suprafamilies Annu. Rev. Biochem. 70, 209- 246

${ }^{4}$ Gerlt, J. A., Babbitt, P. C., and Rayment, I. (2005) Divergent evolution in the enolase superfamily: The interplay of mechanism and specificity Arch. Biochem. Biophys. 433, 59- 70

${ }^{5}$ Gerlt, J. A., Babbitt, P. C., Jacobson, M. P., and Almo, S. C. (2012) Divergent evolution in the enolase superfamily: Strategies for assigning functions J. Biol. Chem. 287, 29- 34

${ }^{6}$ Glasner, M. E., Fayazmanesh, N., Chiang, R. A., Sakai, A., Jacobson, M. P., Gerlt, J. A., and Babbitt, P. C. (2006) Evolution of structure and function in the $O$-succinylbenzoate synthase $/ \mathrm{N}$-acylamino acid racemase family of the enolase superfamily J. Mol. Biol. 360, 228- 250

7 Glasner, M. E., Gerlt, J. A., and Babbitt, P. C. (2006) Evolution of enzyme superfamilies Curr. Opin. Chem. Biol. 10, 492- 497

${ }^{8}$ Neidhart, D. J., Howell, P. L., Petsko, G. A., Powers, V. M., Li, R. S., Kenyon, G. L., and Gerlt, J. A. (1991) Mechanism of the reaction catalyzed by mandelate racemase. 2 . Crystal structure of mandelate racemase at 2.5- $\AA$ resolution: Identification of the active site and possible catalytic residues Biochemistry 30, 9264- 9273

9 Zhao, S., Kumar, R., Sakai, A., Vetting, M. W., Wood, B. M., Brown, S., Bonanno, J. B., Hillerich, B. S., Seidel, R. D., Babbitt, P. C., Almo, S. C., Sweedler, J. V., Gerlt, J. A., Cronan, J. E., and Jacobson, M. P. (2013) Discovery of new enzymes and metabolic pathways by using structure and genome context Nature 502, 698- 702

10 McMillan, A. W., Lopez, M. S., Zhu, M., Morse, B. C., Yeo, I. C., Amos, J., Hull, K., Romo, D., and Glasner, M. E. (2014) Role of an active site loop in the promiscuous activities of Amycolatopsis sp. T-1-60 NSAR/OSBS Biochemistry 53, 4434- 4444

11 Odokonyero, D., Sakai, A., Patskovsky, Y., Malashkevich, V. N., Fedorov, A. A., Bonanno, J. B., Fedorov, E. V., Toro, R., Agarwal, R., Wang, C.,

Biochemistry, Vol 54, No. 17 (May 5, 2015): pg. 2747-2757. DOI. This article is (c) American Chemical Society and permission has been granted for this version to appear in e-Publications@Marquette. American Chemical Society does not grant permission for this article to be further copied/distributed or hosted elsewhere without the express permission from American Chemical Society. 
Ozerova, N. D., Yew, W. S., Sauder, J. M., Swaminathan, S., Burley, S. K., Almo, S. C., and Glasner, M. E. (2014) Loss of quaternary structure is associated with rapid sequence divergence in the OSBS family Proc. Natl. Acad. Sci. U.S.A. 111, 8535- 8540

12 Zhang, X., Kumar, R., Vetting, M. W., Zhao, S., Jacobson, M. P., Almo, S. C., and Gerlt, J. A. (2015) A unique cis-3-hydroxy-I-proline dehydratase in the enolase superfamily J. Am. Chem. Soc. 137, 13881391

${ }^{13}$ Gerlt, J. A. (1998) Enzyme-catalyzed proton transfer reactions to and from carbon. In Bioorganic Chemistry: Peptides and Proteins (Hecht, S. M., Ed.) pp 279- 311, Oxford University Press, New York.

${ }^{14}$ Felfer, U., Goriup, M., Koegl, M. F., Wagner, U., Larissegger-Schnell, B., Faber, K., and Kroutil, W. (2005) The substrate spectrum of mandelate racemase: Minimum structural requirements for substrates and substrate model Adv. Synth. Catal. 347, 951- 961

${ }^{15}$ Felfer, U., Strauss, U. T., Kroutil, W., Fabian, W. M. F., and Faber, K. (2001) Substrate spectrum of mandelate racemase: Part 2. (Hetero)aryl-substituted mandelate derivatives and modulation of activity $\mathrm{J}$. Mol. Catal. B: Enzym. 15, 213- 222

${ }^{16}$ Kenyon, G. L. and Hegeman, G. D. (1970) Mandelic acid racemase from Pseudomonas putida. Evidence favoring a carbanion intermediate in the mechanism of action Biochemistry 9, 4036- 4043

17 Landro, J. A., Kenyon, G. L., and Kozarich, J. W. (1992) Mechanism-based inactivation of mandelate racemase by propargylglycolate Bioorg. Med. Chem. Lett. 2, 1411- 1418

${ }^{18}$ Li, R., Powers, V. M., Kozarich, J. W., and Kenyon, G. L. (1995) Racemization of vinylglycolate catalyzed by mandelate racemase $J$. Org. Chem. 60, 3347-3351

19 Lin, D. T., Powers, V. M., Reynolds, L. J., Whitman, C. P., Kozarich, J. W., and Kenyon, G. L. (1988) Evidence for the generation of a-carboxy-ahydroxy- $p$-xylylene from $p$-(bromomethyl)mandelate by mandelate racemase J. Am. Chem. Soc. 110, 323- 324

20 St. Maurice, M. and Bearne, S. L. (2004) Hydrophobic nature of the active site of mandelate racemase Biochemistry 43, 2524- 2532

${ }^{21}$ St. Maurice, M. and Bearne, S. L. (2002) Kinetics and thermodynamics of mandelate racemase catalysis Biochemistry 41, 4048- 4058

22 Nagar, M., Narmandakh, A., Khalak, Y., and Bearne, S. L. (2011) Redefining the minimal substrate tolerance of mandelate racemase. Racemization of trifluorolactate Biochemistry 50, 8846- 8852

23 Nagar, M., Lietzan, A. D., St. Maurice, M., and Bearne, S. L. (2014) Potent inhibition of mandelate racemase by a fluorinated substrate-product analogue with a novel binding mode Biochemistry 53, 1169- 1178

Biochemistry, Vol 54, No. 17 (May 5, 2015): pg. 2747-2757. DOI. This article is (C) American Chemical Society and permission has been granted for this version to appear in e-Publications@Marquette. American Chemical Society does not grant permission for this article to be further copied/distributed or hosted elsewhere without the express permission from American Chemical Society. 
NOT THE PUBLISHED VERSION; this is the author's final, peer-reviewed manuscript. The published version may be accessed by following the link in the citation at the bottom of the page.

${ }^{24}$ Narmandakh, A. and Bearne, S. L. (2010) Purification of recombinant mandelate racemase: Improved catalytic activity Protein Expression Purif. 69, 39- 46

${ }^{25}$ Sharp, T. R., Hegeman, G. D., and Kenyon, G. L. (1979) A direct kinetic assay for mandelate racemase using circular dichroic measurements Anal. Biochem. 94, 329- 334

${ }^{26}$ Gasteiger, E., Gattiker, A., Hoogland, C., Ivanyi, I., Appel, R. D., and Bairoch, A. (2003) ExPASy: The proteomics server for in-depth protein knowledge and analysis Nucleic Acids Res. 31, 3784- 3788

27 Eng, J., McCormack, A., and Yates, J. (1994) An approach to correlate tandem mass spectral data of peptides with amino acid sequences in a protein database J. Am. Soc. Mass Spectrom. 5, 976- 989

${ }^{28}$ Otwinowski, Z. and Minor, W. (1997) Processing of X-ray diffraction data collected in oscillation mode Methods Enzymol. 276, 307- 326

29 McCoy, A. J., Grosse-Kunstleve, R. W., Adams, P. D., Winn, M. D., Storoni, L. C., and Read, R. J. (2007) Phaser crystallographic software J. Appl. Crystallogr. 40, 658- 674

${ }^{30}$ Emsley, P., Lohkamp, B., Scott, W. G., and Cowtan, K. (2010) Features and development of Coot Acta Crystallogr. D 66, 486- 501

${ }^{31}$ Vagin, A. A., Steiner, R. S., Lebedev, A. A., Potterton, L., McNicholas, S., Long, F., and Murshudov, G. N. (2004) REFMAC5 dictionary: Organisation of prior chemical knowledge and guidelines for its use Acta Crystallogr. D 60, 2284- 2295

32 Urbansky, E. T. and Bashe, W. J. (2000) Comparative methodology in the determination of a-oxocarboxylates in aqueous solution ion chromatography versus gas chromatography after oximation, extraction and esterification J. Chromatogr. A 867, 143- 149

33 Cooper, A. J. L. and Redfield, A. G. (1975) Proton magnetic resonance studies of a-keto acids J. Biol. Chem. 250, 527- 532

34 Meany, J. E. (2007) Lactate dehydrogenase catalysis: Roles of keto, hydrated, and enol pyruvate J. Chem. Educ. 84, 1520- 1523

35 Dunitz, J. D. and Taylor, R. (1997) Organic fluorine hardly ever accepts hydrogen bonds Chem. Eur. J. 3, 89- 98

${ }^{36}$ Olsen, J. A., Banner, D. W., Seiler, P., Wagner, P., Tschopp, T., ObstSander, U., Kansy, M., Müller, K., and Diederich, F. (2004) Fluorine interactions at the thrombin active site: Protein backbone fragments $\mathrm{H}-\mathrm{C}_{\mathrm{a}}-\mathrm{C}=\mathrm{O}$ Comprise a favorable $\mathrm{C}-\mathrm{F}$ environment and interactions of C-F with electrophiles ChemBioChem 5, 666- 675

37 Bégué, J.-P. and Bonnet-Delpon, D. (2008) Bioorganic and Medicinal Chemistry of Fluorine, John Wiley \& Sons, Inc., Hoboken, NJ.

38 St. Maurice, M. and Bearne, S. L. (2000) Reaction intermediate analogues for mandelate racemase: Interaction between Asn 197 and the a-

Biochemistry, Vol 54, No. 17 (May 5, 2015): pg. 2747-2757. DOI. This article is (c) American Chemical Society and permission has been granted for this version to appear in e-Publications@Marquette. American Chemical Society does not grant permission for this article to be further copied/distributed or hosted elsewhere without the express permission from American Chemical Society. 
NOT THE PUBLISHED VERSION; this is the author's final, peer-reviewed manuscript. The published version may be accessed by following the link in the citation at the bottom of the page.

hydroxyl of the substrate promotes catalysis Biochemistry 39, 1332413335

39 Malpica, A. and Calzadilla, M. (2005) Kinetics and mechanism of oxime formation from methyl benzoylformate J. Phys. Org. Chem. 18, 945949

40 Goldstein, J. A., Cheung, Y. F., Marletta, M. A., and Walsh, C. (1978) Fluorinated substrate analogues as stereochemical probes of enzymatic reaction mechanisms Biochemistry 17, 5567- 5575

${ }^{41}$ Hurley, T. J., Carrell, H. L., Gupta, R. K., Schwartz, J., and Glusker, J. P. (1979) The structure of sodium $\beta$-fluoropyruvate: A gem-diol Arch. Biochem. Biophys. 193, 478- 486

42 Parisi, M. F. and Abeles, R. H. (1992) Inhibition of chymotrypsin by fluorinated a-keto acid derivatives Biochemistry 31, 9449- 9435

43 Pocker, Y. and Meany, J. E. (1970) The reversible hydration of pyruvic acid. II. Metal ion and enzymatic catalysis J. Phys. Chem. 74, 1486- 1492

${ }^{44}$ Lawrence, M. C., Barbosa, J. A. R. G., Smith, B. J., Hall, N. E., Pilling, P. A., Ooi, H. C., and Marcuccio, S. M. (1997) Structure and mechanism of a sub-family of enzymes related to $\mathrm{N}$-acetylneuraminate lyase $\mathrm{J}$. Mol. Biol. 266, 381- 399

${ }^{45}$ Dobson, R. C., Griffin, M. D., Devenish, S. R., Pearce, F. G., Hutton, C. A., Gerrard, J. A., Jameson, G. B., and Perugini, M. A. (2008) Conserved main-chain peptide distortions: A proposed role for Ile 203 in catalysis by dihydrodipicolinate synthase Protein Sci. 17, 2080- 2090

${ }^{46}$ Means, G. E. and Feeney, R. E. (1968) Reductive alkylation of amino groups in proteins Biochemistry 7, 2192

47 Hine, J., Cholod, M. S., and Chess, W. K. (1973) Kinetics of the formation of imines from acetone and primary amines. Evidence for internal acidcatalyzed dehydration of certain intermediate carbinolamines J. Am. Chem. Soc. 95, 4270- 4276

48 Hedrick, J. L. and Sallach, H. J. (1961) The metabolism of hydroxypyruvate. I. The nonenzymatic decarboxylation and autoxidation of hydroxypyruvate J. Biol. Chem. 236, 1867- 1871

${ }^{49}$ Spring, T. G. and Wold, F. (1971) Studies on two high-affinity enolase inhibitors. Reaction with enolases Biochemistry 10, 4655- 4660

50 Lane, R. H. and Hurst, J. K. (1974) Intermediates in enolase-catalyzed reactions Biochemistry 13, 3292- 3297

${ }^{51}$ Amyes, T. L. and Richard, J. P. (2013) Specificity in Transition State Binding: The Pauling Model Revisited Biochemistry 52, 2021- 2035

52 Gerlt, J. A. and Babbitt, P. C. (2009) Enzyme (re)design: Lessons from natural evolution and computation Curr. Opin. Chem. Biol. 13, 10- 18

53 Nagano, N., Orengo, C. A., and Thornton, J. M. (2002) One fold with many functions: The evolutionary relationships between TIM barrel families

Biochemistry, Vol 54, No. 17 (May 5, 2015): pg. 2747-2757. DOI. This article is (C) American Chemical Society and permission has been granted for this version to appear in e-Publications@Marquette. American Chemical Society does not grant permission for this article to be further copied/distributed or hosted elsewhere without the express permission from American Chemical Society. 
NOT THE PUBLISHED VERSION; this is the author's final, peer-reviewed manuscript. The published version may be accessed by following the link in the citation at the bottom of the page.

based on their sequences, structures and functions J. Mol. Biol. 321, $741-765$

${ }^{54}$ Murzin, A. G., Brenner, S. E., Hubbard, T., and Chothia, C. (1995) SCOP: A structural classification of proteins database for the investigation of sequences and structures J. Mol. Biol. 247, 536- 540

${ }^{55}$ Fox, N. K., Brenner, S. E., and Chandonia, J. M. (2014) SCOPe: Structural Classification of Proteins-extended, integrating SCOP and ASTRAL data and classification of new structures Nucleic Acids Res. 42, D304D309

56 DeVries, G. H. and Binkley, S. B. (1972) 3-Hydroxy-N-acetylneuraminic acid: Synthesis and inhibitory properties Arch. Biochem. Biophys. 151, $243-250$

57 Brändén, C.-I. (1991) The TIM barrel: The most frequently occurring folding motif in proteins Curr. Opin. Struct. Biol. 1, 978- 983

${ }^{58}$ Farber, G. K. and Petsko, G. A. (1990) The evolution of $a / \beta$ barrel enzymes Trends Biochem. Sci. 15, 228- 234

${ }^{59}$ Farber, G. K. (1993) An a/ $\beta$-barrel full of evolutionary trouble Curr. Opin. Struct. Biol. 3, 409- 412

60 Reardon, D. and Farber, G. K. (1995) The structure and evolution of $a / \beta$ barrel proteins FASEB J. 9, 497- 503

${ }^{61}$ Wierenga, R. K. (2001) The TIM-barrel fold: A versatile framework for efficient enzymes FEBS Lett. 492, 193- 198

${ }^{62}$ Gerlt, J. A. and Raushel, F. M. (2003) Evolution of function in ( $\left.\beta / a\right)_{8}$-barrel enzymes Curr. Opin. Chem. Biol. 7, 252- 264

63 Wilmanns, M., Hyde, C. C., Davies, D. R., Kirschner, K., and Jansonius, J. N. (1991) Structural conservation in parallel $\beta / a$-barrel enzymes that catalyze three sequential reactions in the pathway of tryptophan biosynthesis Biochemistry 30, 9161- 9169

${ }^{64}$ Raine, A. R., Scrutton, N. S., and Mathews, F. S. (1994) On the evolution of alternate core packing in eightfold $\beta /$ a-barrels Protein Sci. 3, 18891892

65 Janeček, S. (1995) Close evolutionary relatedness among functionally distantly related members of the $(a / \beta)_{8}$-barrel glycosyl hydrolases suggested by the similarity of their fifth conserved sequence region FEBS Lett. 377, 6- 8

66 Janeček, S. and Baláz, S. (1995) Functionally essential, invariant glutamate near the $C$-terminus of strand $\beta 5$ in various $(a / \beta)_{8}$-barrel enzymes as a possible indicator of their evolutionary relatedness Protein Eng. 8, 809- 813

${ }^{67}$ Copley, R. R. and Bork, P. (2000) Homology among ( $\left.\beta a\right)_{8}$ barrels: Implications for the evolution of metabolic pathways J. Mol. Biol. 303, $627-641$ 
NOT THE PUBLISHED VERSION; this is the author's final, peer-reviewed manuscript. The published version may be accessed by following the link in the citation at the bottom of the page.

${ }^{68}$ Rakus, J. F., Fedorov, A. A., Fedorov, E. V., Glasner, M. E., Hubbard, B. K., Delli, J. D., Babbitt, P. C., Almo, S. C., and Gerlt, J. A. (2008) Evolution of enzymatic activities in the enolase superfamily: IRhamnonate dehydratase Biochemistry 47, 9944- 9954

${ }^{69}$ Choi, K. H., Lai, V., Foster, C. E., Morris, A. J., Tolan, D. R., and Allen, K. N. (2006) New superfamily members identified for Schiff-base enzymes based on verification of catalytically essential residues Biochemistry $45,8546-8555$

70 O'Brien, P. J. and Herschlag, D. (1999) Catalytic promiscuity and the evolution of new enzymatic activities Chem. Biol. 6, R91- R105

${ }^{71}$ Landro, J. A., Gerlt, J. A., Kozarich, J. W., Koo, C. W., Shah, V. J., Kenyon, G. L., Neidhart, D. J., Fujita, S., and Petsko, G. A. (1994) The role of lysine 166 in the mechanism of mandelate racemase from Pseudomonas putida: Mechanistic and crystallographic evidence for stereospecific alkylation by $(R)$-a-phenylglycidate Biochemistry 33, $635-643$

72 Lietzan, A. D., Nagar, M., Pellmann, E. A., Bourque, J. R., Bearne, S. L., and St. Maurice, M. (2012) Structure of mandelate racemase with bound intermediate analogues benzohydroxamate and Cupferron Biochemistry 51, 1160- 1170

\section{Supporting Information}

Inhibition by a-keto acids (Figures $1 \mathrm{~S}-4 \mathrm{~S}$ ). This material is available free of charge via the Internet at http://pubs.acs.org.

Biochemistry, Vol 54, No. 17 (May 5, 2015): pg. 2747-2757. DOI. This article is @ American Chemical Society and permission has been granted for this version to appear in e-Publications@Marquette. American Chemical Society does not grant permission for this article to be further copied/distributed or hosted elsewhere without the express permission from American Chemical Society. 


\title{
Supporting Information
}

\author{
for
}

\section{Inactivation of Mandelate Racemase by 3-Hydroxypyruvate Reveals a Potential Mechanistic Link Between Enzyme Superfamilies}

Mitesh Nagar, ${ }^{\dagger}$ Brittney N. Wyatt,${ }^{\ddagger}$ Martin St. Maurice, ${ }^{\ddagger}$ and Stephen L. Bearne ${ }^{\dagger, \delta, *}$

$\dagger$ Department of Biochemistry and Molecular Biology, Dalhousie University, Halifax, NS, B3H 4R2, Canada

\$ Department of Biological Sciences, Marquette University, Milwaukee, WI 53201-1881, USA

$\S$ Department of Chemistry, Dalhousie University, Halifax, NS, B3H 4R2, Canada

* Author to whom correspondence should be addressed.

Phone: (902) 494-1974; fax: (902) 494-1355; e-mail: sbearne@dal.ca 
TABLE OF CONTENTS

PAGE

Supplementary Figure 1S Competitive inhibition of MR by mesoxalate (Mox)

Supplementary Figure 2S Competitive inhibition of MR by 3-fluoropyruvate (3-FP)

Supplementary Figure 3S Time-dependence for the inhibition of MR by $\alpha$-keto acids

Supplementary Figure 4S Stereoview of a representative $2 \mathrm{~F}_{\mathrm{o}}-\mathrm{F}_{\mathrm{c}}$ electron density map, contoured at $1.0 \sigma$, for the active site of 3-HP-MR 

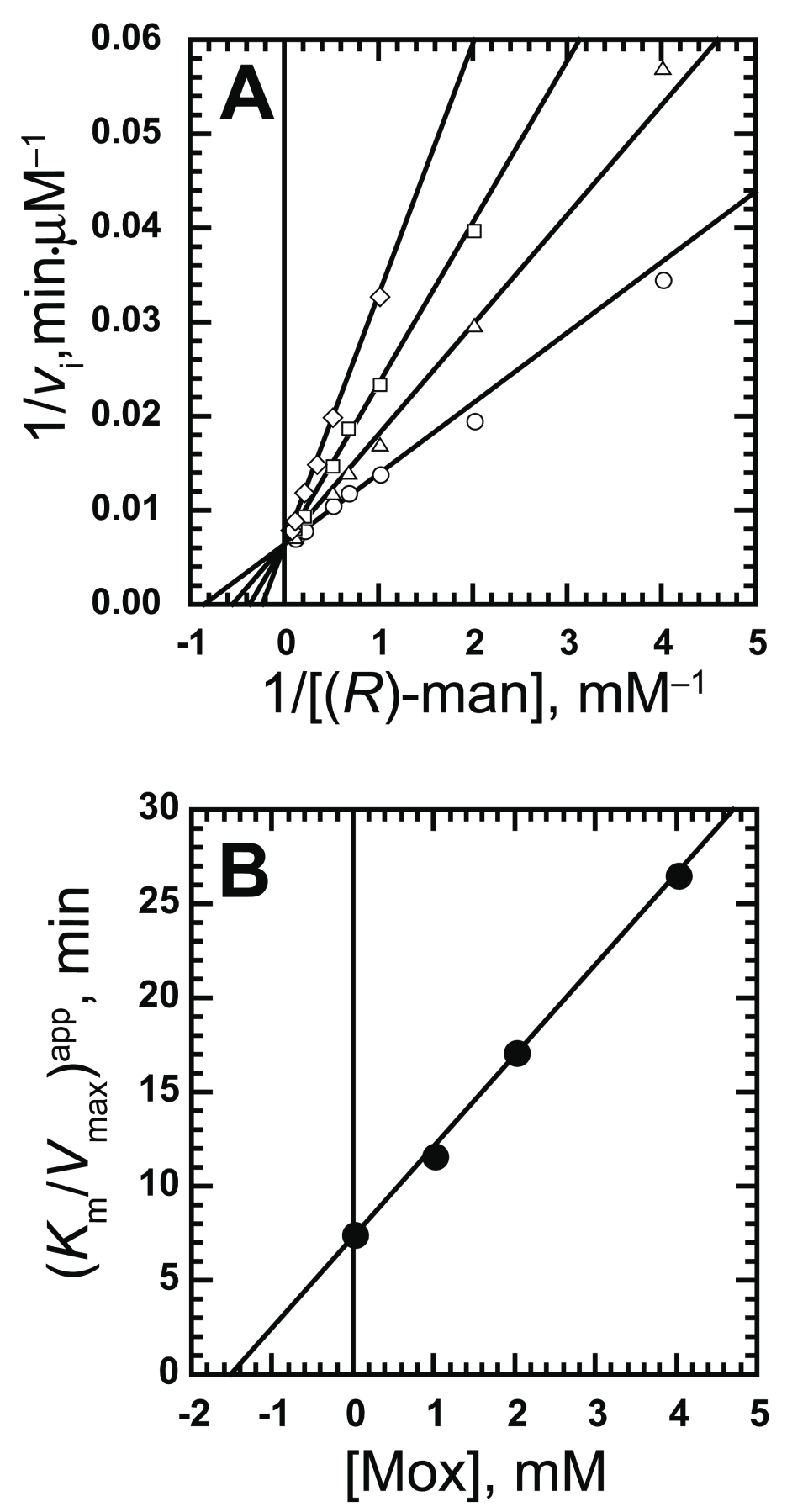

Supplementary Figure 1S. Competitive inhibition of MR by mesoxalate (Mox). Representative Lineweaver-Burk plot. (B) Replot of the apparent $K_{\mathrm{m}} / V_{\max }$ values against inhibitor concentration. Assay conditions are as described in the Materials and Methods. 

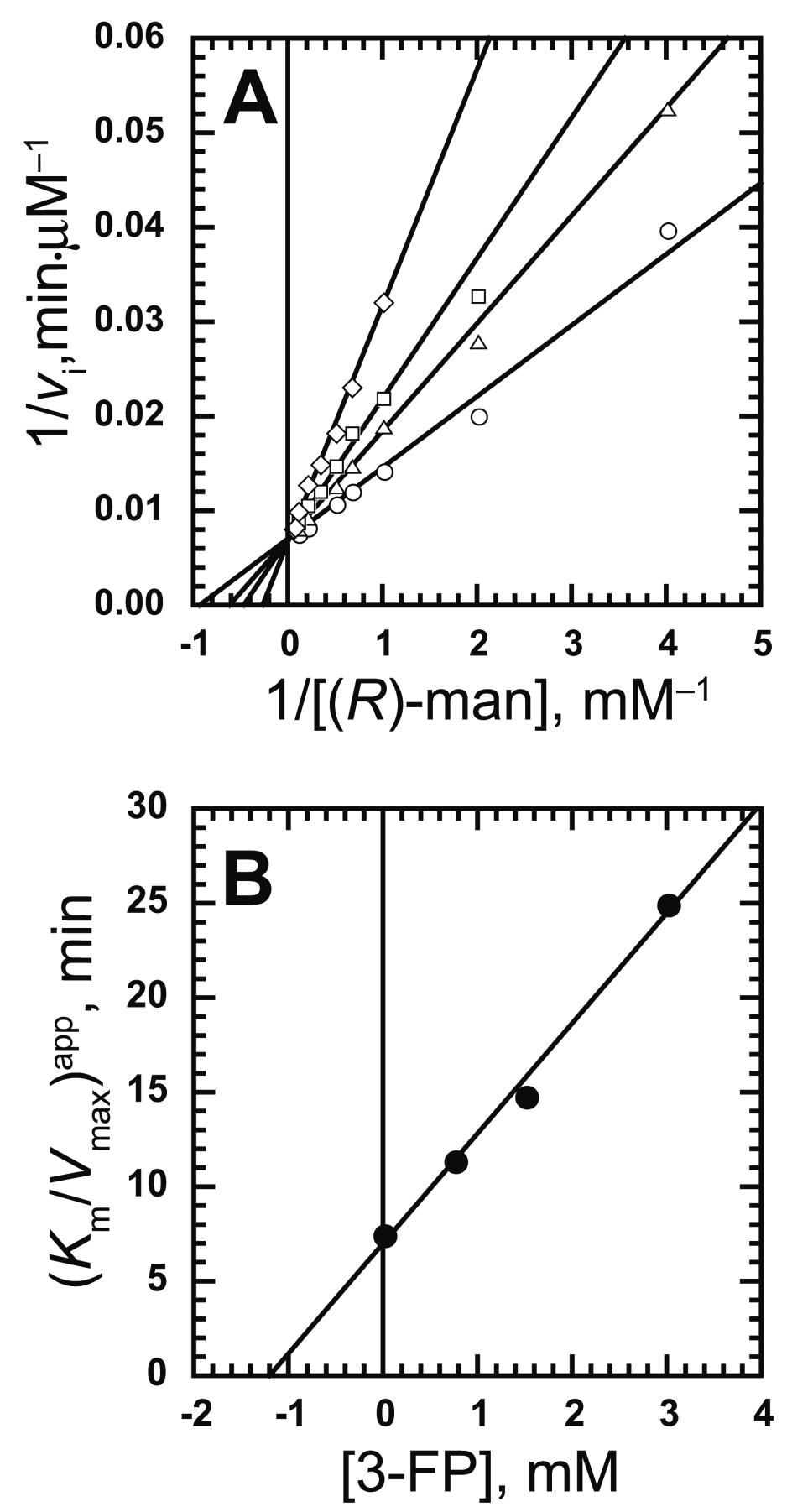

Supplementary Figure 2S. Competitive inhibition of MR by 3-fluoropyruvate (3-FP). (A) Representative Lineweaver-Burk plot. (B) Replot of the apparent $K_{\mathrm{m}} / V_{\max }$ values against inhibitor concentration. Assay conditions are as described in the Materials and Methods. 


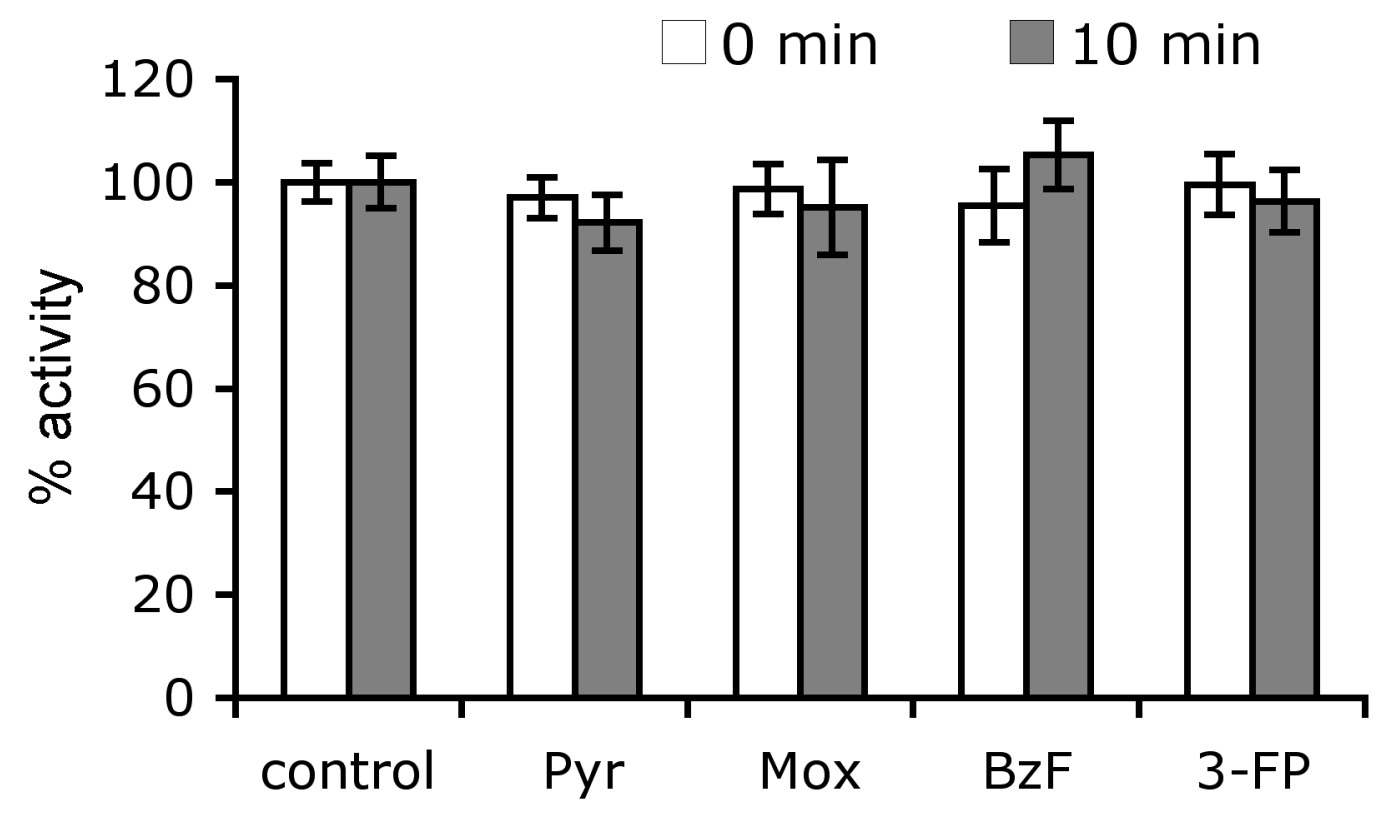

Supplementary Figure 3S. Time-dependence for the inhibition of MR by $\alpha$-keto acids. Pyruvate (Pyr), mesoxalate (Mox), benzoylformate (BzF), and 3-fluoropyruvate (3-FP) do not show significant reduction in MR activity when incubated at concentrations of $2 \mathrm{mM}$ with wildtype MR for $10 \mathrm{~min}$ at $25^{\circ} \mathrm{C}$. 


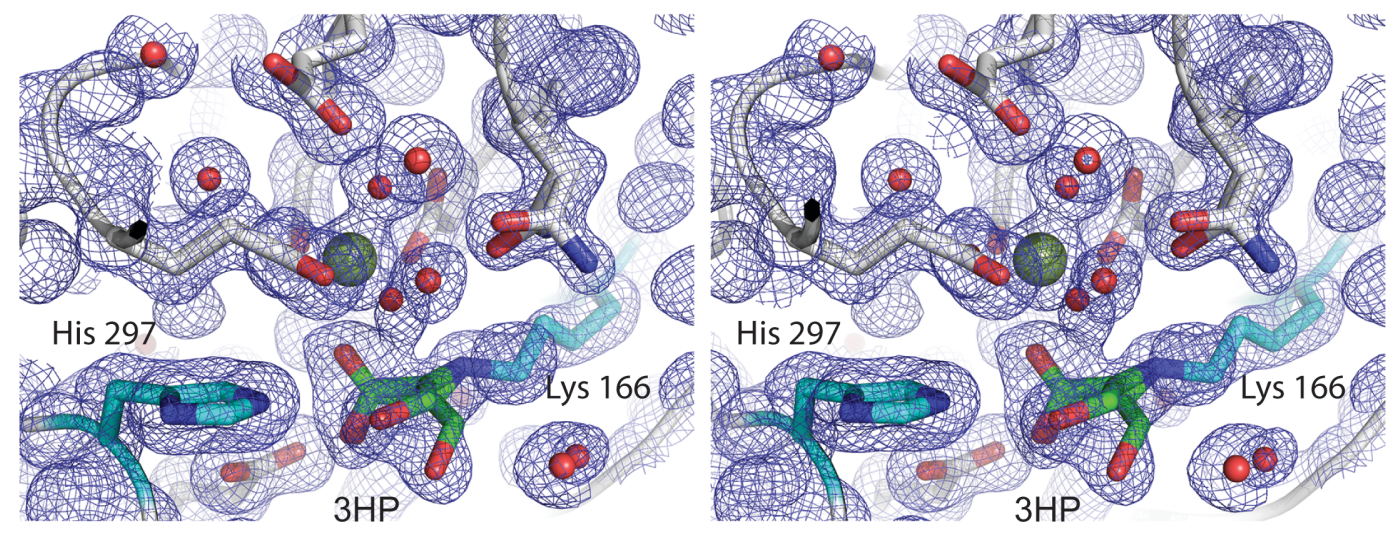

Supplementary Figure 4S. Stereoview of a representative $2 \mathrm{~F}_{\mathrm{o}}-\mathrm{F}_{\mathrm{c}}$ electron density map, contoured at $1.0 \sigma$, for the active site of 3-HP-MR. The Brønsted acid-base catalysts (His 297 and Lys 166) are colored cyan and the 3-HP adduct is colored green. 